\title{
Targeting Mitochondria to Counteract Age-Related Cellular Dysfunction
}

\author{
Corina T. Madreiter-Sokolowski ${ }^{1, *(1)}$, Armin A. Sokolowski ${ }^{2}$, Markus Waldeck-Weiermair ${ }^{1}$, \\ Roland Malli ${ }^{1,3}$ and Wolfgang F. Graier ${ }^{1,3, * \text { iD }}$ \\ 1 Molecular Biology and Biochemistry, Gottfried Schatz Research Center, Medical University of Graz; \\ Neue Stiftingtalstraße 6/6, 8010 Graz, Austria; markus.weiermair@medunigraz.at (M.W.-W.); \\ roland.malli@medunigraz.at (R.M.) \\ 2 Department of Dentistry and Maxillofacial Surgery, Medical University of Graz; Billrothgasse 4, 8010 Graz, \\ Austria; armin.sokolowski@medunigraz.at \\ 3 BioTechMed, Mozartgasse 12/2, 8010 Graz, Austria \\ * Correspondences: corina.madreiter@medunigraz.at (C.T.M.-S.); wolfgang.graier@medunigraz.at (W.F.G.); \\ Tel.: +43-316-385-71957 (C.T.M.-S.); +43-316-385-71963 (W.F.G.)
}

Received: 10 January 2018; Accepted: 15 March 2018; Published: 16 March 2018

\begin{abstract}
Senescence is related to the loss of cellular homeostasis and functions, which leads to a progressive decline in physiological ability and to aging-associated diseases. Since mitochondria are essential to energy supply, cell differentiation, cell cycle control, intracellular signaling and $\mathrm{Ca}^{2+}$ sequestration, fine-tuning mitochondrial activity appropriately, is a tightrope walk during aging. For instance, the mitochondrial oxidative phosphorylation (OXPHOS) ensures a supply of adenosine triphosphate (ATP), but is also the main source of potentially harmful levels of reactive oxygen species (ROS). Moreover, mitochondrial function is strongly linked to mitochondrial $\mathrm{Ca}^{2+}$ homeostasis and mitochondrial shape, which undergo various alterations during aging. Since mitochondria play such a critical role in an organism's process of aging, they also offer promising targets for manipulation of senescent cellular functions. Accordingly, interventions delaying the onset of age-associated disorders involve the manipulation of mitochondrial function, including caloric restriction (CR) or exercise, as well as drugs, such as metformin, aspirin, and polyphenols. In this review, we discuss mitochondria's role in and impact on cellular aging and their potential to serve as a target for therapeutic interventions against age-related cellular dysfunction.
\end{abstract}

Keywords: mitochondria; aging; caloric restriction; exercise; caloric restriction mimetics; polyphenols; aspirin

\section{Introduction}

In a rapidly aging society, new treatment options for age-related disorders and diseases will be increasingly important [1,2]. Consequently, in recent decades, research has focused heavily on the processes of aging to reveal potential targets for prolonging health and lifespan [3]. Consistent with this, interventions such as caloric restriction (CR) [3] or exercise [4], as well as pharmacological strategies $[5,6]$ have been well established to improve health and to slow down aging [7]. Aging is linked to the progressive decline of a cell's or organism's capacity to counteract stress, damage, and disease [8], resulting in impaired physiological function, pathologies, and death [9]. Cellular hallmarks of aging are shared among various organisms and include genomic instability, telomere attrition, stem cell exhaustion and mitochondrial dysfunction $[8,10]$. During senescence cells lose their proliferation potential and develop a senescence-associated secretory phenotype (SASP) [11]. Through secretion of pro-inflammatory cytokines, chemokines, and tissue-damaging proteases, among other factors, the SASP has local and systemic pathogenic effects on surrounding cells [12]. Senescent 
cells also undergo a shift in metabolism, including a change in glycolytic flux and mitochondrial respiration, thereby affecting nearby cells [13].

As adenosine triphosphate (ATP)-producing power plants of the cell, mitochondria are in a unique position to influence an organism's aging process. Recent reports suggest that mitochondrial function is linked to age-associated biphasic alterations in metabolic activity, including an increase and afterwards progressive decrease in mitochondrial function [3]. In addition, the byproducts of mitochondrial respiration, reactive oxygen species (ROS), are key determinants in the initiation of cellular senescence when present in high concentrations [14]. Moreover, changes in mitochondrial dynamics in fusion and fission, as well as alterations in the mitochondrial membrane potential [15] have been reported to cause cellular dysfunctions during senescence [16]. Hence, changes in mitochondrial $\mathrm{Ca}^{2+}$ homeostasis, as well as in endoplasmic reticulum (ER)-mitochondria crosstalk, could reduce the adaptive capacity of cells to withstand stress and increase their vulnerability to age-related diseases [17]. Consequently, it seems reasonable that life-prolonging interventions, such as CR [3] or exercise [4], as well as various drugs [5,6], target mitochondria. Remarkably, reduction of mitochondrial content in vivo has recently been reported to reduce the spectrum of senescence effectors and phenotypes in mice [18]. Nevertheless, since mitochondrial activity changes in a biphasic manner during aging [3], the right interventions need to be set at the right time to successfully counteract age-associated cellular dysfunction instead of triggering it.

Notably, impaired mitochondrial functions were reported to cause accelerated aging that affects primarily organs with high levels of energy demand, such as the brain, the heart, the skeletal muscle, as well as liver and kidney [19]. The critical role of mitochondria in these organs becomes clinically visible in the case of mitochondrial diseases that frequently affect organs with high energy demand, showing clinical features of encephalopathy, dementia, myopathy, exercise intolerance, cardiomyopathy, optic atrophy, liver failure [20], and renal pathologies [21]. In addition, the link between mitochondrial dysfunction and age-related diseases is well-established for Alzheimer's disease [22], myocardial infarction, and sarcopenia [23]. Notably, the role of mitochondria seems to also be crucial in malignant tumor progression [24], thus, studies that unveil mitochondrial targets, which may serve as potential candidates for new and promising therapeutic strategies against cancer [25], are needed.

This review provides a summary of present knowledge about mitochondria's unique role in the process of aging and the development of age-related disorders and diseases. Furthermore, the potential of mitochondria to serve as targets for therapeutic interventions against age-related diseases is highlighted.

\section{Mitochondria}

As descendants of $\alpha$-proteobacteria, mitochondria are double-membraned and equipped with their own circular genome. After 1.5 billion years of incorporation into the eukaryotic cell, mitochondria are well-integrated and irreplaceable cellular compartments [26]. While the majority of mitochondrial proteins are nuclear-encoded and actively imported into mitochondria [27], the 16.6-kilobase mitochondrial genome includes genetic information for mitochondrial ribosomal and transfer RNA and proteins of the mitochondrial respiration complexes [28]. Since a human requires $65 \mathrm{~kg}$ ATP per day on average, mitochondria, as the main producers of cellular ATP, have a Herculean task to fulfill as the most efficient production sites of the cell's current ATP [29].

The protein complexes of the mitochondrial respiration chain are located at the cristae [30]. These infoldings of the inner mitochondrial membrane (IMM) stretch deeply into the matrix, which results in an enormous increase of surface area [31,32]. While the outer mitochondrial membrane (OMM) links mitochondria to other organelles, such as plasma membrane and the ER, and consists of many passive and nonselective transporters, regulating barely the transport of molecules from the cytosol into the intermembrane space (IMS) [33], the IMM has a strongly restricted transport system and a high density of proteins [34]. To fulfill their tasks, mitochondria change their morphology and structure rapidly and continuously undergo fission and fusion [35]. Different proteins are responsible 
for mitochondrial fusion, including mitofusin 1 (MFN1) and mitofusin 2 (MFN2) in the OMM as well as optic atrophy 1 (OPA1) in the IMM, and for fission, as, for instance, dynamin-related protein 1 (DRP1) [35].

To ensure and control mitochondrial $\mathrm{Ca}^{2+}$ uptake from the IMS to the mitochondrial matrix, a complex machinery of proteins is located at the IMM [36]. Mitochondrial $\mathrm{Ca}^{2+}$ uptake is linked to $\mathrm{Ca}^{2+}$ mobilization from the biggest internal $\mathrm{Ca}^{2+}$ store, the ER [37], or the entrance of extracellular $\mathrm{Ca}^{2+}[38]$. The close contact between plasma membrane and ER is essential for a process known as store-operated $\mathrm{Ca}^{2+}$ entry (SOCE). In this process low $\mathrm{Ca}^{2+}$ levels in the ER cause oligomerization and, finally, a conformational change of the $\mathrm{Ca}^{2+}$ sensing stromal interaction molecule-1 (STIM1), which then activates the plasma membrane $\mathrm{Ca}^{2+}$ channel (ORAI1) through protein-protein interactions, causing $\mathrm{Ca}^{2+}$ entry [39]. Cytosolic $\mathrm{Ca}^{2+}$ elevations are sensed by mitochondria, which take up $\mathrm{Ca}^{2+}$ to buffer cytosolic $\mathrm{Ca}^{2+}$ levels in distinct regions of the cytosol, so-called microdomains, and thereby control the activity of $\mathrm{Ca}^{2+}$-dependent enzymes [40] and ion channels [41]. Mitochondria are also able to re-shuffle entering $\mathrm{Ca}^{2+}$ to the ER [42]. Moreover, the $\mathrm{Na}^{+} / \mathrm{Ca}^{2+}$ exchanger (NCX) and the plasma membrane $\mathrm{Ca}^{2+}$ ATPase (PMCA) also regulate cytosolic $\mathrm{Ca}^{2+}$ levels by extrusion of $\mathrm{Ca}^{2+}[43]$.

A finely-tuned complex of proteins ensures and controls the mitochondrial $\mathrm{Ca}^{2+}$ uptake, including the pore-forming mitochondrial calcium uniporter (MCU) [44,45], which exists as a hetero-oligomer with its negative regulator mitochondrial calcium uniporter b (MCUb) [46]. Moreover, the essential MCU regulator (EMRE) [47] links the $\mathrm{Ca}^{2+}$-sensing proteins mitochondrial $\mathrm{Ca}^{2+}$ uptake 1 (MICU1) and mitochondrial $\mathrm{Ca}^{2+}$ uptake 2 (MICU2), which control mitochondrial $\mathrm{Ca}^{2+}$ homeostasis, to MCU [48]. In addition, several other proteins are involved in MCU-dependent mitochondrial $\mathrm{Ca}^{2+}$ uptake, including mitochondrial calcium uniporter regulator 1 (MCUR1) [49], the EF-hand domain containing protein SLC25A23 [50] as well as the uncoupling proteins 2 and 3 (UCP2/3) [51]. Recently, a role for MCU's cysteine 97 was identified in ROS sensing and the positive regulation of MCU activity, potentially leading to a feedback mechanism for mitochondrial $\mathrm{Ca}^{2+}$ uptake [52].

In the mitochondrial matrix, $\mathrm{Ca}^{2+}$ ions control the activity of the tricarboxylic acid (TCA) cycle by $\mathrm{Ca}^{2+}$-dependent dehydrogenases $[53,54]$. The reduction equivalents from the TCA cycle, nicotinamide adenine dinucleotide $(\mathrm{NADH})$ and flavin adenine dinucleotide $\left(\mathrm{FADH}_{2}\right)$, donate electrons to the electron transport chain (ECT). Electrons are accepted at the NADH dehydrogenase (complex I) and cytochrome bc1 complex (complex III) and are shuttled via succinate dehydrogenase (complex II), ubiquinone, cytochrome bc1 complex (complex III), and cytochrome $c$ to cytochrome $c$ oxidase (complex IV), where $\mathrm{O}_{2}$ is reduced to $\mathrm{H}_{2} \mathrm{O}$. The electron transport through complex I to complex IV is coupled to proton pumping from the mitochondrial matrix to the IMS. The electrochemical gradient produced is used for the proton transport from the IMS into the matrix through ATP synthase (complex V), causing a release of energy and phosphorylation of adenosine diphosphate (ADP) to ATP [55]. If electrons are incompletely transferred to complex I or complex III, superoxide anions are generated [56]. To neutralize these potentially harmful byproducts of mitochondrial respiration, mitochondrial manganese superoxide dismutase (MnSOD, SOD2) converts superoxide anions to $\mathrm{H}_{2} \mathrm{O}_{2}$ [57]. While a large portion of $\mathrm{H}_{2} \mathrm{O}_{2}$ may diffuse from the mitochondria to the cytosol, in the matrix of mitochondria several enzymes, like peroxiredoxins (PRDX) 3 and 5, catalase, and glutathione peroxidases 1 and 4 reduce $\mathrm{H}_{2} \mathrm{O}_{2}$ to $\mathrm{H}_{2} \mathrm{O}$ [57]. Notably, $\mathrm{H}_{2} \mathrm{O}_{2}$ is also linked to the NAD and NADP systems and is a key signaling molecule [58]. Hence, reduction of mitochondrial $\mathrm{H}_{2} \mathrm{O}_{2}$ by overexpression of PRDX3 improved glucose tolerance in mice, potentially via inhibition of glycogen synthase kinase-3. Moreover, cells from animals overexpressing PRDX3 had increased resistance to stress-induced cell death and apoptosis [59]. High levels of ROS have harmful effects on their surroundings, including the mitochondrial genome (mtDNA) and proteins, and are, thereby, key determinants in the initiation of cellular senescence [60]. In contrast, low levels of ROS evoke a vaccination-like response, resulting in a strengthened defense shield against ROS, which positively impacts lifespan by increased detoxification of newly-produced ROS [61]. Interestingly, $\mathrm{Mclk}^{+/-}$mutant mice that produce higher levels of ROS than wild-type mice, had an enhanced immune reactivity and slowed aging progression [62]. 
Moreover, activation of the intrinsic apoptotic pathway by mitochondrial ROS was reported to induce a protective response and improve longevity in Caenorhabditis elegans (C. elegans) [63].

While mitochondria ensure cell viability by ATP production, they also execute programmed cell death [64]. In response to death-inducing stimuli like metabolic perturbation or oncogene activation, mitochondrial permeability increases. In this regard, the protein OPA1 of the IMM, which tightens cristae junctions by oligomerization, plays a crucial role. The pro-apoptotic BCL-2 family members induce disruption of OPA1 oligomers and thereby widen cristae junctions, causing enhanced permeability [65] and release of second mitochondria-derived activators of caspases (SMACs) and cytochrome $c$ into the cytosol through a mechanism yet to be described [66]. By deactivating proteins that inhibit apoptosis (IAPs), SMACs indirectly activate caspases. In addition, cytochrome $c$ binds to apoptotic protease activating factor 1 (APAF1) and ATP, forming the apoptosome complex, which cleaves pro-caspase 9 into its active form caspase-9, and thereby activates effector caspases [67]. During senescence this process of programmed cell death is less tightly regulated, leading to accumulation of dysfunctional and damaged cells [68].

Since all of these mitochondrial tasks are highly complex and need to be well-balanced and controlled, numerous targets may be affected by aging or impacted by dysregulation of the process of aging.

\section{Mitochondrial Changes during Aging}

\subsection{Mitochondrial $\mathrm{Ca}^{2+}$ Homeostasis}

During the process of aging, the protein machinery controlling mitochondrial $\mathrm{Ca}^{2+}$ uptake and homeostasis undergoes remarkable changes. For instance, the MCU channel is oxidized by ROS, resulting in increased MCU channel activity, which, in turn, further elevates mitochondrial ROS levels and increases the risk for mitochondrial $\mathrm{Ca}^{2+}$ overload-induced cell death [52]. Moreover, the expression of MCU, as well as the crosstalk between ER and mitochondria was increased in long-term cultured rat hippocampal neurons, leading to elevated mitochondrial $\mathrm{Ca}^{2+}$ levels, while store-operated $\mathrm{Ca}^{2+}$ entry was inhibited via downregulation of STIM1 and ORAI1 in these aging neurons [69]. In line with that, replicative senescence and oncogene-induced senescence caused mitochondrial $\mathrm{Ca}^{2+}$ accumulation by inositol 1,4,5-trisphosphate receptor type 2 (ITPR 2 )-triggered $\mathrm{Ca}^{2+}$ release from the ER and mitochondrial $\mathrm{Ca}^{2+}$ uptake via MCU in human mammary epithelial cells (HMEC). In turn, loss of ITPR 2 and MCU counteracted the development of senescence [70]. Mitochondrial $\mathrm{Ca}^{2+}$ overload, as well as high levels of ROS promotes cell death by collapse of the mitochondrial membrane potential and opening of the mitochondrial permeability transition pore (mPTP) [71]. Moreover, age-associated loss of mitochondrial membrane potential [15] might further increase the risk of mPTP opening [71]. Release of metabolites such as ROS, $\mathrm{Ca}^{2+}, \mathrm{NAD}^{+}$, and glutathione into the cytosol was shown to disrupt cellular homeostasis and to increase oxidative damage [72] and possibly cause a decline in mitochondrial function. Indeed, mitochondrial $\mathrm{Ca}^{2+}$ flux in response to cytosolic $\mathrm{Ca}^{2+}$ was reported to decrease progressively in C. elegans during aging [73]. The importance of sufficient mitochondrial $\mathrm{Ca}^{2+}$ uptake was demonstrated in mice lacking Fus1, a small mitochondrial protein regulating mitochondrial $\mathrm{Ca}^{2+}$ homeostasis. Loss of Fus1 caused inefficient accumulation of $\mathrm{Ca}^{2+}$ in mitochondria and decreased respiratory reserve capacity, resulting in the decreased lifespan of mice with knockout of Fus1 [74]. These partly conflicting results suggest that fine-tuning of mitochondrial $\mathrm{Ca}^{2+}$ homeostasis during aging is a tightrope walk between meeting mitochondria's demand for $\mathrm{Ca}^{2+}[74]$ and triggering harmful processes like increased ROS production or mPTP opening by $\mathrm{Ca}^{2+}$ overload [74].

\subsection{Mitochondrial Respiration, Reactive Oxygen Species Production, and Reactive Oxygen Species Defense}

Aging was typically associated with decreased mitochondrial metabolism [10]. In apparent contradiction, approaches to extend lifespan are frequently linked to a reduction in energy intake 
and decreased overall energy production [75]. The hypothesis about a biphasic regulation of metabolism during aging developed in response, suggesting increased mitochondrial activity in middle-age followed by constant decline in advanced age [3]. In support of this, TCA metabolites changed in a biphasic manner in rhesus monkeys, including a decrease in the $\mathrm{NAD}^{+} / \mathrm{NADH}$ ratio at middle-age (15-16 years) and elevation in increased age (28-32 years) [76]. Moreover, since changes in mitochondrial $\mathrm{Ca}^{2+}$ levels mirrored those in energy production-initially elevated $[52,69]$ before they declined as a result of mitochondrial $\mathrm{Ca}^{2+}$ overload-induced damage [72] - it seems safe to assume that mitochondrial respiration is boosted at middle-age. Since increased mitochondrial respiration is linked to elevated levels of ROS, enhanced mitochondrial respiration at middle age may promote cellular damage by ROS [3]. Therefore, a well-developed antioxidant defense shield might be necessary to counteract ROS-induced cellular dysfunction [61]. In this regard, a study with transgenic mice overexpressing human catalase in peroxisomes, nucleus, or mitochondria highlighted the importance of mitochondrial antioxidant defense mechanisms, showing that median and maximum life span were maximally increased in mitochondrial catalase-overexpressing animals [77]. Another study failed to see a positive impact of catalase overexpression or combined overexpression of MnSOD with cytosolic copper-zinc superoxide dismutase CuZnSOD, as well as of catalase with CuZnSOD on the lifespan of mice. Notably, catalase overexpression in this transgenic mouse model occurred in peroxisomes [78]. Interestingly, overexpression of cytosolic thioredoxin 1 was reported to extend mainly the earlier part of murine lifespan, but not to affect maximum life span [79]. It seems likely that the ROS-defense system might be successful just to a certain extent and simply delay the onset of mitochondrial respiration dysfunction and decline, possibly differing within the various species. In old normal human fibroblasts (NHFs), oxygen consumption rate (OCR), and ATP levels significantly increased, while glycolytic flux and lactate levels decreased [13]. In contrast, in murine brain and liver the content and activity of critical enzymes of mitochondrial function, including complex I and complex III, as well as MnSOD, decreased with age. Decline was detected after 28 weeks and progressed further until 92 weeks [80]. Consistent with this, brain mitochondria from aging mice (16-24 months) exhibited decreased $\mathrm{F}_{1} \mathrm{~F}_{\mathrm{O}}$ ATP synthase activity and defective $\mathrm{F}_{1} \mathrm{~F}_{\mathrm{O}}$ complex coupling, which may be caused by the mitochondrial protein cyclophilin D [81]. Moreover, in cardio myocytes of middle-aged rats (two years) the efficiency of the creatine kinase phospho-transfer pathways declined during senescence, which resulted in reduced oxidative phosphorylation (OXPHOS), decreased affinity of mitochondrial ADP and, ultimately, decreased heart muscle performance [82]. In summary, studies from various cell types and animals in different studies do not allow a clear conclusion yet but make further studies necessary with regard to a potentially biphasic metabolic change during aging.

\subsection{Mitochondrial Genome and Unfolded Protein Response}

Mutations of mitochondrial DNA (mtDNA) are estimated to be 10- to 17-fold higher than in the nuclear genome [83]. In line with the free radical theory of aging overwhelming ROS production is the main cause for this damage to the mitochondrial genome, which is especially susceptible to this type of genomic damage due to a lack of histones and limited DNA repair mechanisms [84]. Consequently, a well-developed antioxidant defense offered protection from mitochondrial dysfunction and resulted in greater longevity in various species [84]. In addition, antioxidants counteracted cell cycle arrest and aging, induced by mtDNA double-strand breaks, in mice [85]. Studies in conplastic mouse strains further highlighted the crucial role of mtDNA, demonstrating that different mtDNA variants are able to promote alterations in mitochondrial function and cellular adaptive responses which impact metabolic performance and aging [86]. Point mutations in mtDNA significantly accumulated in brain mitochondria of aged mice and caused mitochondrial dysfunction by altering the OXPHOS machinery [87]. However, a high percentage of mutated mtDNA is necessary to induce dysfunction and diseases [88]. Levels of mtDNA in mouse liver and uterus decreased significantly during aging and mtDNA copy numbers were reduced in aged oocytes [89]. Notably, high levels of mtDNA deletions were reported for specific regions of the human brain [90] and substantia nigra neurons [91,92]. 
Moreover, an accumulation of mtDNA deletions was also found in aged human skeletal muscle fibers [93]. Since mtDNA encodes essential parts of the OXPHOS machinery, deletion of mtDNA causes OXPHOS dysfunction and a decline of cellular function [88]. The induction of mitochondrial unfolded protein response (UPR ${ }^{\mathrm{mt}}$ ) was suggested as a possible mechanism to tolerate mtDNA deletions to a certain extent [88]. UPR ${ }^{\mathrm{mt}}$ is a protective transcriptional program from the cells to sense and respond to mitochondrial dysfunction by inducing mitochondrial protein homeostasis and regeneration of defective mitochondria [94]. In a heteroplasmic C. elegans strain, containing wild-type mtDNA and mtDNA lacking four essential genes, $\mathrm{UPR}^{\mathrm{mt}}$ was constitutively activated by dysfunctional OXPHOS. Moreover, even deleterious mtDNA was maintained by $\mathrm{UPR}^{\mathrm{mt}}$, possibly in an attempt to recover OXPHOS activity by promoting mitochondrial biogenesis [88]. It was shown in C. elegans that OXPHOS dysfunction induces the activating transcription factor associated with stress (ATFS1), which binds directly to the OXPHOS gene promotors in the nuclear and mitochondrial genomes and thereby promotes OXPHOS recovery during the UPR ${ }^{\mathrm{mt}}$ [95]. In mammals the transcription factor ATF5 was found to induce similar transcriptional responses as ATFS1 in C. elegans and even rescued $\mathrm{UPR}^{\mathrm{mt}}$ signaling in ATFS1 deficient worms [94]. Furthermore, in mammalian cells, it was shown that mitochondrial protein folding stress activates chaperone availability and reduces protein synthesis in the matrix via translational inhibition. The crucial impact of $U_{P R}{ }^{\mathrm{mt}}$ on the process of aging was demonstrated in worms, in which UPR ${ }^{\mathrm{mt}}$ delayed aging and promoted life span via ATFS1 [96]. Recently, UPR ${ }^{\mathrm{mt}}$ was also shown to prolong the lifespan of Drosophila melanogaster by activation of the forkhead protein $\mathrm{O}$ (FOXO), which induces a set of chaperones implicated in lifespan extension [97].

\subsection{Mitochondrial Mass and Structure}

The main transcription factor of UPR ${ }^{\mathrm{mt}}$ in nematodes, ATFS1, controls mitochondrial biogenesis to compensate for loss of OXPHOS activity [95]. Consequently, mitochondrial mass might be increased in the case of UPR ${ }^{\mathrm{mt}}$ activation during aging [98]. Indeed, a progressive accumulation of mitochondria during the process of aging was described for the nematode C. elegans and linked to age-related decline in so-called mitophagy [99]. After mitochondria are replicated via symmetric fission, they are in a constant fusion and fission process. However, damage occurs over time or as a consequence of stress and the defective mitochondria are removed via a specific degradation pathway, mitophagy, to keep the host cell alive [100]. For efficient mitophagy, an intact fission complex is required [101]. Notably, in neurons from aged rhesus macaques, a phenomenon called mitochondria-on-a-string (MOAS), characterized by thin segments of mitochondria mixed with large ones, a phenotype already described for neurodegenerative diseases, was found and linked to incomplete mitochondrial fission due to dysregulation of the fission machinery [102]. Short-term induction of mitochondrial fission in midlife by DRP1overexpression enhanced mitophagy in D. melanogaster. A shift towards accumulation of dysfunctional elongated mitochondria was thereby prevented and health, as well as lifespan, improved significantly [103]. Notably, increased levels of mitochondrial fission proteins FIS1 and DRP1 were also reported for middle-aged mice (15 months) [104]. Nevertheless, the function of FIS1 in mitochondrial fission of human cells is questioned by findings demonstrating that FIS1 is not required for fission, but for the disposal of defective mitochondria [105]. Consistent with this finding, FIS1 was also reported as an essential part of the mitophagy process [106]. However, enhanced mitochondrial fission might be a defense mechanism of mitochondria in middle-age, but mitochondria's ability to alter the structure in order to control function might be exhausted in old age. For instance, mitochondrial fusion was induced by the increased activity of MFN1and OPA1 in old NHFs [13]. Moreover, an expression decline of MFN1, MFN2, OPA1, and DRP1 caused age-related muscle loss in humans and mice, which could be counteracted by lifelong regular exercise [107]. Acute depletion of OPA1 resulted in mitochondria of smaller size, mitochondrial dysfunction, and ER stress, inducing muscle loss and aging [107]. In long-lived D. melanogaster (10-12 weeks), mitochondria showed cristae vacuolization and the distribution of functional proteins such as ATP synthase was hampered [108]. Another study also confirmed a disruption of the IMM organization in old D. melanogaster, characterized by the lack of 
well-developed cristae and cristae junctions and positively correlating with the rate of mitochondrial respiration [109]. In contrast, the changes in mitochondrial ultrastructure were less apparent and strongly tissue-specific in aged mice. Mitochondria of mouse liver exhibited the strongest age-specific phenotype, which was characterized by a central matrix void, but did not result in a reduction of OXPHOS [109]. In cardiomyocytes of 24-month old rats the number of mitochondrial cristae was markedly reduced, their parallel position was lost, and they did not fill the entire mitochondrial matrix. Consistent with this finding, the surface area of the IMM was reported to be decreased in aged rats [110]. In yeast, age-associated accumulation of sphingoid bases, aliphatic amino alcohols, including sphingosine, caused fragmentation of the mitochondrial network, resulting in impaired mitochondrial respiration, loss of mitochondrial membrane potential, and a decline in lifespan [111]. In summary, these recent reports demonstrate that alterations of mitochondrial structure during aging have wide-ranging effects on mitochondrial and cellular function, but might offer unique targets to manipulate mitochondrial function.

\section{Targeting Mitochondria to Counteract Aging}

\subsection{Behavioral Interventions}

Caloric restriction: From C. elegans [112] to primates [113], caloric restriction (CR) has been shown to counteract age-related decline and to increase lifespan $[114,115]$. The occurrence of metabolic, neurological, and cardiovascular diseases was decreased by a $20-40 \%$ reduction in caloric intake [116]. While reducing the overall metabolism, CR was reported to shift the metabolism from carbohydrate to fatty acid metabolism, strongly stimulating mitochondrial energy production [75]. CR also enhanced the activity of complex IV as well as ROS-producing complexes I and III in the brains of mice, causing elevated MnSOD activity and redox capacity in CR brains [117]. Consistent with that, low levels of mitochondrial ROS were reported to initiate health-promoting antioxidant defense mechanisms and increase life span via so-called "mitohormesis" [118]. The effect of CR is not just limited to mitochondrial respiration. In liver mitochondria of mice, $\mathrm{Ca}^{2+}$ retention capacity was enhanced strongly by CR in comparison to ad libitum diet, offering protection from ischemia/reperfusion damage, a condition frequently observed in age [119]. Additionally, CR decreased the activity of cyclophilin D through deacetylation, resulting in the increased capacity of mitochondria to buffer $\mathrm{Ca}^{2+}$ and enhanced tolerance against excitotoxicity in rat brain mitochondria [117]. In yeast, CR optimized the signaling pathway of SNF1, the yeast orthologue to AMP-activated protein kinase (AMPK), thereby regulating cellular energy homeostasis and extending life span [120]. Moreover, short-term CR, as well as CR mimetic drugs like metformin or resveratrol, activated AMPK-mechanistic target of rapamycin (mTOR) signaling in aging kidney tissues, as well as in human primary proximal tubular cells [121]. AMPK was shown to stimulate sirtuin 1 (SIRT1) via an increase in NAD ${ }^{+}$levels [122] and to induced mitochondrial biogenesis [123]. Indeed, CR increased expression of SIRT1 and transcription factor a (TFAM), directly stimulating mtDNA replication and transcription, and resulted in increased mitochondrial content and function in skeletal muscle of healthy, non-obese humans [124]. Nevertheless, the impact of CR on mitochondrial function in humans during aging was questioned by a recent study showing that 12 months of a $25 \%$ CR did not affect muscle mitochondrial function and oxidative stress in healthy, non-obese humans. Only individuals with a higher ATP flux $/ \mathrm{O}_{2}$ ratio at baseline benefited from CR in regard to muscle mitochondrial ATP synthesis rates and coupling [125]. These contradictory results might suggest that the right timing determines the outcome of CR, as well as the individual's ability to react to this intervention.

Exercise: In a number of species, age-related muscle loss is linked to impaired mitochondrial biogenesis and function, as well as to decreased metabolic capacity [126]. Proliferator-activated receptor $\gamma$ co-activator $1 \alpha$ (PGC-1 $\alpha$ ) crucially contributes to mitochondrial biogenesis by activating nuclear respiratory factors (NRF1 and NRF2), which promote expression of nuclear-encoded mitochondrial proteins, and TFAM [127]. In old mice, PGC-1 $\alpha$ and mitochondrial sirtuin 3 (SIRT3) 
were downregulated [128]. Notably, exercise normalized age-related changes of these proteins and, in addition, the expression of catalase, was enhanced by exercise, potentially contributing to improved resilience of arteries in exercising mice by elevated ROS defense mechanisms [128]. Additionally, in muscles of aged rats, PGC- $1 \alpha$ and TFAM were found to be downregulated and, in line, mtDNA content was decreased. Interestingly, the aging-related decline of the PGC- $1 \alpha$ signaling pathway could be reversed by exercise, increasing levels of PGC- $1 \alpha$, TFAM and the mtDNA content. These training effects were linked to increased expression of AMPK, p38 mitogen-activated kinase (MAPK) and SIRT1, potentially functioning as up-stream targets of exercise [127]. In addition to mitochondrial biogenesis, mitochondrial $\mathrm{Ca}^{2+}$ homeostasis has also been shown to be affected during aging, revealing downregulation of MCU in aged mice [4]. Analysis of muscle biopsies from 70-year old subjects revealed changes in proteins involved in mitochondrial $\mathrm{Ca}^{2+}$ uptake and in mitochondrial shape by nine weeks of physical training or neuromuscular electrical stimulation. Improved muscle function and structure by both types of training were linked to increased protein levels of MCU. Interestingly, electron microscopy revealed remodeling of mitochondrial shape in muscles trained by electrical stimulation, which was potentially mediated by an increased expression of cristae structure-shaping protein OPA1 [4]. Interestingly, endurance exercise also normalized redox homeostasis and induced a change in the subcellular localization of p53 to mitochondria versus nucleus, which was linked to beneficial effects on mitochondrial function and maintenance of mtDNA stability [129].

\subsection{Pharmacological Strategies}

Polyphenols: Polyphenols, such as resveratrol (RSV) or green tea polyphenols, were shown to extend lifespan in Saccharomyces cerevisiae [130], C. elegans [131], D. melanogaster [132], fish [133], and mice [134]. Moreover, the low incidence of coronary heart disease in French people despite the rather high intake of dietary cholesterol and saturated fat, known as the French paradox, was hypothesized to be due to frequent consumption of RSV-rich red wine [135]. Clinical trials confirmed that RSV is safe and well-tolerated, but also demonstrated the very poor bioavailability of RSV [136]. The low bioavailability of RSV in combination with its low approximate concentration in red wine (0.1-14.3 mg/L) [136], as well as the enormous toxic effects induced by ethanol, makes red wine unlikely to serve as a fountain of youth [137]. However, recent studies suggest that high intake of fat is even associated with lower total mortality, while high carbohydrate intake was linked to a higher risk of total mortality [138]. Thus, the hypothesis about a crucial role of RSV's in the French paradox has to be reevaluated.

Nevertheless, RSV was found to mimic features of CR, such as glucagon and catecholamine release, boosting cyclic adenosine monophosphate production, which, in turn, activates cell-type dependent effectors and leads to elevated $\mathrm{Ca}^{2+}$ levels and activation of the CaMKK $\beta$-AMPK pathway [139]. Enhanced AMPK activity was reported to stimulate SIRT1 via an increase in NAD ${ }^{+}$levels [122]. Other reports claimed that RSV directly activates SIRT1 $[140,141]$, causing enhanced mitochondrial biogenesis [142] and altered metabolism [5]. Moreover, RSV was also reported to trigger mitochondrial respiration and ROS production at low concentrations [143]. Low levels of ROS might stimulate AMPK activity [144] as well as the development of antioxidant defense mechanisms, which might, in turn, result in extended lifespan [145]. Nevertheless, the individual ability to develop defense mechanisms against ROS might be necessary for RSV to impact age-related dysfunctions and diseases positively [143]. For instance, in an Alzheimer's disease model, RSV failed to reduce elevated $\mathrm{H}_{2} \mathrm{O}_{2}$ production, whereas the ubiquinone derivative, MitoQ, an electron scavenger preventing mitochondrial ROS formation [146], could normalize $\mathrm{H}_{2} \mathrm{O}_{2}$ levels under this condition [147].

Antioxidants: In addition to MitoQ, the Murphy lab has synthesized several other mitochondria-targeted antioxidants by covalently attaching lipophilic triphenylphosphonium cations to endogenous antioxidants, including $\alpha$-tocopherol (MitoVitE) and the synthetic spin trap compound $\alpha$-phenyl-tert-butylnitrone (MitoPBN) [148]. Furthermore, they created the mitochondrial-targeted piperidine nitroxide MitoTEMPOL [149]. Due to mitochondrial accumulation, these compounds 
exhibited more enhanced protective effects than untargeted analogs [148]. In rat brains, MitoQ suppressed peroxynitrite-mediated mitochondrial function induced by lead toxicity [150]. Furthermore, MitoQ was renoprotective in diabetic mice, possibly via an action of uncoupling [151]. In addition, oral administration of MitoQ reversed aortic stiffness in old mice [152]. MitoQ was even approved for use in humans. Twenty-eight days of oral MitoQ (40 or $80 \mathrm{mg} /$ day) supplementation decreased liver damage in a phase II study of hepatitis C patients [153]. Moreover, the novel mitochondrial-targeted antioxidant elamipretide (SS-31), whose mode of action is still under investigation [154], was successfully tested in a clinical trial about heart failure treatment [155] and is currently under trial as a potential therapy of mitochondrial diseases [156]. All of these results prove that an imbalance in ROS signaling plays a crucial role in various diseases and aging.

Nevertheless, the relevance of antioxidants in preventing age-related cellular dysfunction by the reduction of oxidative stress was challenged by the finding that small levels of ROS provoke a vaccination-like stimulus, thus causing development of antioxidant defense mechanisms and a positive impact on lifespan [118]. Consequently, researchers have suggested an inverted U-shaped dose-response relationship between ROS levels and lifespan. In support, the three antioxidants N-acetylcysteine, vitamin C and RSV lengthened lifespan at low concentrations and shortened lifespan at high concentrations in C. elegans [157]. The difficulty in finding the right dosage might explain controversial outcomes of clinical trials regarding antioxidant supplementation therapies in humans [158]. In animals, as well, no conclusive statement regarding the success of treatment with antioxidants is possible. Administration of MitoQ to 24-month-old mice for 15 weeks did not reduce mitochondria ROS levels or normalize mitochondrial membrane potential and respiration in muscle tissues. Moreover, there was no effect on lifespan [159]. In contrast, in mice with mtDNA mutations, which accelerate aging, the mitochondria-targeted antioxidant SkQ1 counteracted increased mitochondrial ROS levels and improved health and lifespan [160]. In the case of aging, it might be difficult to find the right dosage and to identify the therapeutic window in which treatment with antioxidants may be beneficial, since the individual ROS defense mechanisms is likely to undergo changes, possibly in a biphasic modulation [3].

Aspirin: Long-term usage of acetylsalicylic acid $\left(\right.$ Aspirin $\left.{ }^{\circledR}\right)$, a nonsteroidal anti-inflammatory drug, was shown to slightly increase the lifespan of worms [161], flies [162], and mammals [163]. After oral administration, aspirin is metabolized to salicylate [6]. This metabolite was shown to activate AMPK in HEK-293 cells directly, critically influencing cell growth and metabolism. Accordingly, fatty acid oxidation, associated with increased phosphorylation of AMPK, was stimulated by salicylate in isolated hepatocytes of mice [6]. Additionally, in C. elegans, aspirin treatment increased the expression of lipid hydrolysis and fatty acid $\beta$-oxidation-related genes, which activated DAF-12 and DAF-16, the worm orthologue to FOXO, and extended lifespan [161]. Nevertheless, despite reducing the risk for colorectal cancer [164] and potentially contributing to cardioprotection [165,166], the successful use of aspirin in humans to increase health and lifespan has yet to be tested in a clinical trial and is rather questionable due to a simultaneously increased risk of gastrointestinal bleeding [167].

Omega-3 fatty acids: Treatment with $\omega-3$ fatty acid $\alpha$-linolenic acid (ALA) increased lifespan of C. elegans via the activation of the transcription factors NHR-49, the worm orthologue of human PPAR $\alpha$, and SKN1, the worm orthologue of human NRF2. NHR-49-activated genes are involved in the $\beta$-oxidation of free fatty acids, promoting the generation of energy via mitochondrial respiration and NRF2-induced mitochondrial biogenesis [168]. In the brains of aged mice, exhibiting reduced ATP levels and decreased activity of complexes I, II and IV of the mitochondrial respiration system, $\omega-3$ polyunsaturated fatty acids from fish oil induced neuroprotective actions and improved mitochondrial ATP production and function [169]. Consistent with these findings, $\omega-3$ polyunsaturated fatty acids increased mitochondrial protein synthesis and significantly reduced mitochondrial oxidative stress in aged humans (65-85) [170]. Nevertheless, conclusive clinical trials about the impact of $\omega-3$ fatty acids on health and lifespan of humans are still missing and, consequently, their potential as anti-aging drugs is elusive. 
Metformin: Metformin, a biguanide used for diabetes prevention and management for 60 years, was reported to display greatly beneficial effects on aging in cellular and animal models, as well as in pilot human studies, far beyond that expected from improving glycemic control [1]. Despite its successful use in the treatment of type-2 diabetes by glucose-lowering and insulin-sensitizing effects, the mode of action of this drug remains largely elusive. One reason for its therapeutic actions might be the inhibition of mitochondrial respiration by reducing the activity of complex I and ATP synthase as well as by stimulating ROS production [171], possibly ending in a process of mitohormesis [118]. That metformin drastically affects metabolism, was further highlighted by the finding that metformin effectively reduces acetyl coenzyme A (CoA) synthesis [172]. Moreover, reduction in mitochondrial respiratory capacity resulted in inactivation of mechanistic target of rapamycin complex 1 (mTORC1), which inhibited growth via the mitochondrial $\beta$-oxidation regulator acyl-CoA dehydrogenase family member-10 (ACAD10). Accordingly, ACAD10 was necessary for the lifespan-extending effect of metformin in C. elegans [173]. As a caloric-restriction mimetic, metformin was believed to inhibit mTORC1 through AMPK by increasing the cellular AMP/ATP ratio. However, inhibition of mTORC1 signaling was even found in the absence of AMPK [174] and inhibition of mTORC1 down-regulated nuclear-encoded mitochondrial genes, resulting in decreased mitochondrial biogenesis and mitochondrial respiration [175]. Interestingly, the sensitivity of cells to metformin is strongly dependent on their ability to cope with energetic stress [176]. Consequently, metformin might induce a senolytic effect [177], causing specific cell death in aged cells with decreased compensatory mechanisms to counteract changes in cellular metabolism.

Senolytics: Senolytic drugs were reported to induce apoptosis of senescent cells, thus preventing the local and systemic pathogenic effects of senescent cells conveyed by the release of proinflammatory cytokines and chemokines, tissue-damaging proteases and inhibition of stem and progenitor cell function [12]. By hosting various proteins of the apoptosis machinery, mitochondria are in a unique position to mediate the effects of these drugs [64]. Accordingly, the first senolytic agents discovered all affected mitochondria, including dasatinib, quercetin, and navitoclax [12]. The cancer drug dasatinib, a tyrosine kinase inhibitor approved for treatment of chronic myeloid leukemia, was reported to regulate mitochondrial biogenesis via increased expression of PGC-1 $\alpha$ [178] and to increase mitochondrial ROS production drastically [179]. Navitoclax, in use to treat various types of cancer, targets BCL-2 proteins and thereby specifically kills cancer and senescent cells [180]. Moreover, as in RSV, the polyphenol quercetin was shown to modulate mitochondrial function in a concentration-dependent manner [181]. Therefore, the specific metabolic pattern, as well as the ability to compensate for changes in metabolism during aging, might be crucial for the compounds' mode of action. However, researchers have not yet specifically investigated how these compounds work, nor how to recognize the right timing for an intervention.

\section{Conclusions}

The process of aging evokes various alterations in mitochondrial $\mathrm{Ca}^{2+}$ handling [17], mitochondrial respiration [80], mitochondrial structure [13], as well as in the mitochondrial genome [84], which are mutually interrelated to each other. Results from cell culture and animal experiments suggest enhanced mitochondrial activity in middle age, but a decline in old age [3]. Initially, increased activity of mitochondria might compensate for the decreased mitochondrial efficiency that occurs during aging. However, this enhanced mitochondrial activity might harm the cell long-term, for instance, by increased ROS production, and might even further promote age-related cellular dysfunction (Figure 1). Interventions, like CR [117], exercise [128], and drugs, such as polyphenols [139], antioxidants [160], metformin [171], $\omega-3$ fatty acids [168], aspirin [6], and senolytics [12], specifically target mitochondria and thereby successfully counteract these age-related damages. Nevertheless, it seems critical when intervention is brought to bear and at which time. Accordingly, clinical studies often yield inconclusive results with regard to anti-aging interventions [158]. 
Consequently, it is of major importance to further investigate the molecular processes behind the role of mitochondria in aging, as well as their potential to serve as targets for therapeutic interventions.

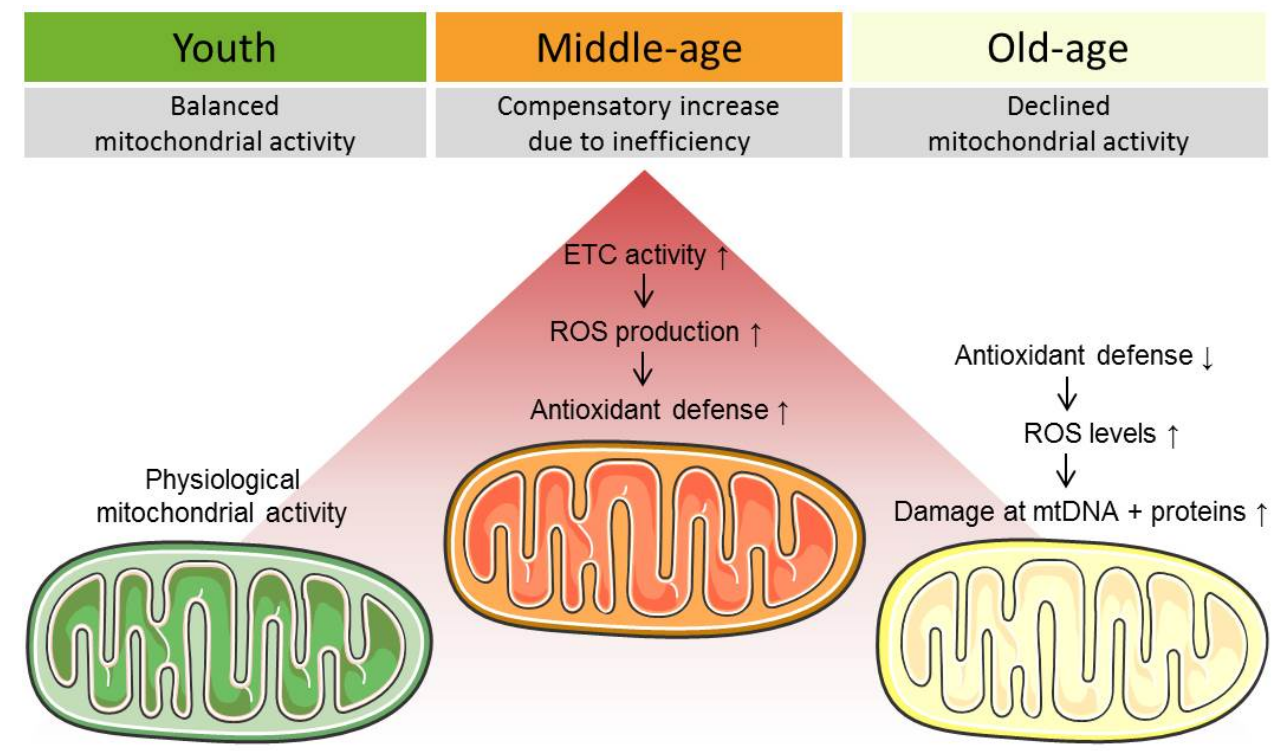

Age-related cellular dysfunction

Figure 1. Biphasic alterations of mitochondrial function during aging. ETC: Electron transport chain, ROS: Reactive oxygen species, Mito: Mitochondrial, MtDNA: Mitochondrial desoxyribonucleic acid. Created using Servier Medical Art (Les Laboratoires Servier, Suresnes, France).

Acknowledgments: We greatly thank Jesse Hay and Kimberly Swanson for proofreading our manuscript.

Author Contributions: C.T.M.-S., A.A.S., M.W.-W., R.M., and W.F.G. prepared the review and discussed its content and structure.

Conflicts of Interest: The authors declare no conflict of interest.

\section{References}

1. Valencia, W.M.; Palacio, A.; Tamariz, L.; Florez, H. Metformin and ageing: Improving ageing outcomes beyond glycaemic control. Diabetologia 2017, 60, 1630-1638. [CrossRef] [PubMed]

2. Childs, B.G.; Durik, M.; Baker, D.J.; van Deursen, J.M. Cellular senescence in aging and age-related disease: From mechanisms to therapy. Nat. Med. 2015, 21, 1424-1435. [CrossRef] [PubMed]

3. Baker, D.J.; Peleg, S. Biphasic modeling of mitochondrial metabolism dysregulation during aging. Trends Biochem. Sci. 2017, 42, 702-711. [CrossRef] [PubMed]

4. Zampieri, S.; Mammucari, C.; Romanello, V.; Barberi, L.; Pietrangelo, L.; Fusella, A.; Mosole, S.; Gherardi, G.; Hofer, C.; Lofler, S.; et al. Physical exercise in aging human skeletal muscle increases mitochondrial calcium uniporter expression levels and affects mitochondria dynamics. Physiol. Rep. 2016, 4, e13005. [CrossRef] [PubMed]

5. Houtkooper, R.H.; Pirinen, E.; Auwerx, J. Sirtuins as regulators of metabolism and healthspan. Nat. Rev. Mol. Cell Biol. 2012, 13, 225-238. [CrossRef] [PubMed]

6. Hawley, S.A.; Fullerton, M.D.; Ross, F.A.; Schertzer, J.D.; Chevtzoff, C.; Walker, K.J.; Peggie, M.W.; Zibrova, D.; Green, K.A.; Mustard, K.J.; et al. The ancient drug salicylate directly activates AMP-activated protein kinase. Science 2012, 336, 918-922. [CrossRef] [PubMed]

7. Huffman, D.M.; Schafer, M.J.; LeBrasseur, N.K. Energetic interventions for healthspan and resiliency with aging. Exp. Gerontol. 2016, 86, 73-83. [CrossRef] [PubMed]

8. Ocampo, A.; Reddy, P.; Izpisua Belmonte, J.C. Anti-aging strategies based on cellular reprogramming. Trends Mol. Med. 2016, 22, 725-738. [CrossRef] [PubMed] 
9. Farfariello, V.; Iamshanova, O.; Germain, E.; Fliniaux, I.; Prevarskaya, N. Calcium homeostasis in cancer: A focus on senescence. Biochim. Biophys. Acta 2015, 1853, 1974-1979. [CrossRef] [PubMed]

10. Lopez-Otin, C.; Blasco, M.A.; Partridge, L.; Serrano, M.; Kroemer, G. The hallmarks of aging. Cell 2013, 153, 1194-1217. [CrossRef] [PubMed]

11. Tchkonia, T.; Zhu, Y.; van Deursen, J.; Campisi, J.; Kirkland, J.L. Cellular senescence and the senescent secretory phenotype: Therapeutic opportunities. J. Clin. Investig. 2013, 123, 966-972. [CrossRef] [PubMed]

12. Kirkland, J.L.; Tchkonia, T.; Zhu, Y.; Niedernhofer, L.J.; Robbins, P.D. The clinical potential of senolytic drugs. J. Am. Geriatr. Soc. 2017, 65, 2297-2301. [CrossRef] [PubMed]

13. Son, J.M.; Sarsour, E.H.; Kakkerla Balaraju, A.; Fussell, J.; Kalen, A.L.; Wagner, B.A.; Buettner, G.R.; Goswami, P.C. Mitofusin 1 and optic atrophy 1 shift metabolism to mitochondrial respiration during aging. Aging Cell 2017, 16, 1136-1145. [CrossRef] [PubMed]

14. Davalli, P.; Mitic, T.; Caporali, A.; Lauriola, A.; D'Arca, D. ROS, cell senescence, and novel molecular mechanisms in aging and age-related diseases. Oxid. Med. Cell. Longev. 2016, 2016, 3565127. [CrossRef] [PubMed]

15. Stockl, P.; Zankl, C.; Hutter, E.; Unterluggauer, H.; Laun, P.; Heeren, G.; Bogengruber, E.; Herndler-Brandstetter, D.; Breitenbach, M.; Jansen-Durr, P. Partial uncoupling of oxidative phosphorylation induces premature senescence in human fibroblasts and yeast mother cells. Free Radic. Biol. Med. 2007, 43, 947-958. [CrossRef] [PubMed]

16. Park, Y.Y.; Lee, S.; Karbowski, M.; Neutzner, A.; Youle, R.J.; Cho, H. Loss of MARCH5 mitochondrial E3 ubiquitin ligase induces cellular senescence through dynamin-related protein 1 and mitofusin 1. J. Cell Sci. 2010, 123, 619-626. [CrossRef] [PubMed]

17. Fernandez-Sanz, C.; Ruiz-Meana, M.; Miro-Casas, E.; Nunez, E.; Castellano, J.; Loureiro, M.; Barba, I.; Poncelas, M.; Rodriguez-Sinovas, A.; Vazquez, J.; et al. Defective sarcoplasmic reticulum-mitochondria calcium exchange in aged mouse myocardium. Cell Death Dis. 2014, 5, e1573. [CrossRef] [PubMed]

18. Correia-Melo, C.; Marques, F.D.; Anderson, R.; Hewitt, G.; Hewitt, R.; Cole, J.; Carroll, B.M.; Miwa, S.; Birch, J.; Merz, A.; et al. Mitochondria are required for pro-ageing features of the senescent phenotype. EMBO J. 2016, 35, 724-742. [CrossRef] [PubMed]

19. Gonzalez-Freire, M.; de Cabo, R.; Bernier, M.; Sollott, S.J.; Fabbri, E.; Navas, P.; Ferrucci, L. Reconsidering the role of mitochondria in aging. J. Gerontol. A Biol. Sci. Med. Sci. 2015, 70, 1334-1342. [CrossRef] [PubMed]

20. Chinnery, P.F. Mitochondrial disorders overview. In Genereviews ${ }^{\circledR}$; Adam, M.P., Ardinger, H.H., Pagon, R.A., Wallace, S.E., Bean, L.J.H., Stephens, K., Amemiya, A., Eds.; University of Washington: Seattle, WA, USA, 1993.

21. Martin-Hernandez, E.; Garcia-Silva, M.T.; Vara, J.; Campos, Y.; Cabello, A.; Muley, R.; Del Hoyo, P.; Martin, M.A.; Arenas, J. Renal pathology in children with mitochondrial diseases. Pediatr. Nephrol. 2005, 20, 1299-1305. [CrossRef] [PubMed]

22. Lunnon, K.; Keohane, A.; Pidsley, R.; Newhouse, S.; Riddoch-Contreras, J.; Thubron, E.B.; Devall, M.; Soininen, H.; Kloszewska, I.; Mecocci, P.; et al. Mitochondrial genes are altered in blood early in Alzheimer's disease. Neurobiol. Aging 2017, 53, 36-47. [CrossRef] [PubMed]

23. Pestronk, A.; Keeling, R.; Choksi, R. Sarcopenia, age, atrophy, and myopathy: Mitochondrial oxidative enzyme activities. Muscle Nerve 2017, 56, 122-128. [CrossRef] [PubMed]

24. Zong, W.X.; Rabinowitz, J.D.; White, E. Mitochondria and cancer. Mol. Cell 2016, 61, 667-676. [CrossRef] [PubMed]

25. Cardenas, C.; Muller, M.; McNeal, A.; Lovy, A.; Jana, F.; Bustos, G.; Urra, F.; Smith, N.; Molgo, J.; Diehl, J.A.; et al. Selective vulnerability of cancer cells by inhibition of $\mathrm{Ca}^{+}$transfer from endoplasmic reticulum to mitochondria. Cell Rep. 2016, 14, 2313-2324. [CrossRef] [PubMed]

26. Degli Esposti, M. Bioenergetic evolution in proteobacteria and mitochondria. Genome Biol. Evol. 2014, 6, 3238-3251. [CrossRef] [PubMed]

27. Richter-Dennerlein, R.; Oeljeklaus, S.; Lorenzi, I.; Ronsor, C.; Bareth, B.; Schendzielorz, A.B.; Wang, C.; Warscheid, B.; Rehling, P.; Dennerlein, S. Mitochondrial protein synthesis adapts to influx of nuclear-encoded protein. Cell 2016, 167, 471-483. [CrossRef] [PubMed]

28. Lewis, S.C.; Uchiyama, L.F.; Nunnari, J. ER-mitochondria contacts couple mtDNA synthesis with mitochondrial division in human cells. Science 2016, 353, aaf5549. [CrossRef] [PubMed]

29. Rich, P. Chemiosmotic coupling: The cost of living. Nature 2003, 421, 583. [CrossRef] [PubMed] 
30. Cogliati, S.; Frezza, C.; Soriano, M.E.; Varanita, T.; Quintana-Cabrera, R.; Corrado, M.; Cipolat, S.; Costa, V.; Casarin, A.; Gomes, L.C.; et al. Mitochondrial cristae shape determines respiratory chain supercomplexes assembly and respiratory efficiency. Cell 2013, 155, 160-171. [CrossRef] [PubMed]

31. Zoratti, M.; Szabo, I. Electrophysiology of the inner mitochondrial membrane. J. Bioenerg. Biomembr. 1994, 26, 543-553. [CrossRef] [PubMed]

32. Lu, Y.W.; Claypool, S.M. Disorders of phospholipid metabolism: An emerging class of mitochondrial disease due to defects in nuclear genes. Front. Genet. 2015, 6, 3. [CrossRef] [PubMed]

33. Gellerich, F.N.; Trumbeckaite, S.; Opalka, J.R.; Seppet, E.; Rasmussen, H.N.; Neuhoff, C.; Zierz, S. Function of the mitochondrial outer membrane as a diffusion barrier in health and diseases. Biochem. Soc. Trans. 2000, 28, 164-169. [CrossRef] [PubMed]

34. Frazier, A.E.; Chacinska, A.; Truscott, K.N.; Guiard, B.; Pfanner, N.; Rehling, P. Mitochondria use different mechanisms for transport of multispanning membrane proteins through the intermembrane space. Mol. Cell. Biol. 2003, 23, 7818-7828. [CrossRef] [PubMed]

35. Ni, H.M.; Williams, J.A.; Ding, W.X. Mitochondrial dynamics and mitochondrial quality control. Redox Biol. 2015, 4, 6-13. [CrossRef] [PubMed]

36. Kamer, K.J.; Mootha, V.K. MICU1 and MICU2 play nonredundant roles in the regulation of the mitochondrial calcium uniporter. EMBO Rep. 2014, 15, 299-307. [CrossRef] [PubMed]

37. Naghdi, S.; Waldeck-Weiermair, M.; Fertschai, I.; Poteser, M.; Graier, W.F.; Malli, R. Mitochondrial Ca ${ }^{2+}$ uptake and not mitochondrial motility is required for STIM1-Orai1-dependent store-operated $\mathrm{Ca}^{2+}$ entry. J. Cell Sci. 2010, 123, 2553-2564. [CrossRef] [PubMed]

38. Waldeck-Weiermair, M.; Deak, A.T.; Groschner, L.N.; Alam, M.R.; Jean-Quartier, C.; Malli, R.; Graier, W.F. Molecularly distinct routes of mitochondrial $\mathrm{Ca}^{2+}$ uptake are activated depending on the activity of the sarco/endoplasmic reticulum $\mathrm{Ca}^{2+}$ ATPase (SERCA). J. Biol. Chem. 2013, 288, 15367-15379. [CrossRef] [PubMed]

39. Prinz, W.A. Bridging the gap: Membrane contact sites in signaling, metabolism, and organelle dynamics. J. Cell Biol. 2014, 205, 759-769. [CrossRef] [PubMed]

40. Racioppi, L.; Means, A.R. Calcium/calmodulin-dependent protein kinase kinase 2: Roles in signaling and pathophysiology. J. Biol. Chem. 2012, 287, 31658-31665. [CrossRef] [PubMed]

41. Malli, R.; Frieden, M.; Osibow, K.; Graier, W.F. Mitochondria efficiently buffer subplasmalemmal Ca ${ }^{2+}$ elevation during agonist stimulation. J. Biol. Chem. 2003, 278, 10807-10815. [CrossRef] [PubMed]

42. Malli, R.; Frieden, M.; Osibow, K.; Zoratti, C.; Mayer, M.; Demaurex, N.; Graier, W.F. Sustained Ca ${ }^{2+}$ transfer $^{2+}$ across mitochondria is essential for mitochondrial $\mathrm{Ca}^{2+}$ buffering, sore-operated $\mathrm{Ca}^{2+}$ entry, and $\mathrm{Ca}^{2+}$ store refilling. J. Biol. Chem. 2003, 278, 44769-44779. [CrossRef] [PubMed]

43. Brini, M.; Carafoli, E. The plasma membrane $\mathrm{Ca}^{2+}$ ATPase and the plasma membrane sodium calcium exchanger cooperate in the regulation of cell calcium. Cold Spring Harb. Perspect. Biol. 2011, 3, a004168. [CrossRef] [PubMed]

44. Baughman, J.M.; Perocchi, F.; Girgis, H.S.; Plovanich, M.; Belcher-Timme, C.A.; Sancak, Y.; Bao, X.R.; Strittmatter, L.; Goldberger, O.; Bogorad, R.L.; et al. Integrative genomics identifies MCU as an essential component of the mitochondrial calcium uniporter. Nature 2011, 476, 341-345. [CrossRef] [PubMed]

45. De Stefani, D.; Raffaello, A.; Teardo, E.; Szabo, I.; Rizzuto, R. A forty-kilodalton protein of the inner membrane is the mitochondrial calcium uniporter. Nature 2011, 476, 336-340. [CrossRef] [PubMed]

46. Raffaello, A.; De Stefani, D.; Sabbadin, D.; Teardo, E.; Merli, G.; Picard, A.; Checchetto, V.; Moro, S.; Szabo, I.; Rizzuto, R. The mitochondrial calcium uniporter is a multimer that can include a dominant-negative pore-forming subunit. EMBO J. 2013, 32, 2362-2376. [CrossRef] [PubMed]

47. Vais, H.; Mallilankaraman, K.; Mak, D.O.; Hoff, H.; Payne, R.; Tanis, J.E.; Foskett, J.K. EMRE is a matrix Ca ${ }^{2+}$ sensor that governs gatekeeping of the mitochondrial $\mathrm{Ca}^{2+}$ uniporter. Cell Rep. 2016, 14, 403-410. [CrossRef] [PubMed]

48. Patron, M.; Checchetto, V.; Raffaello, A.; Teardo, E.; Vecellio Reane, D.; Mantoan, M.; Granatiero, V.; Szabo, I.; De Stefani, D.; Rizzuto, R. MICU1 and MICU2 finely tune the mitochondrial $\mathrm{Ca}^{2+}$ uniporter by exerting opposite effects on MCU activity. Mol. Cell 2014, 53, 726-737. [CrossRef] [PubMed]

49. Mallilankaraman, K.; Cardenas, C.; Doonan, P.J.; Chandramoorthy, H.C.; Irrinki, K.M.; Golenar, T.; Csordas, G.; Madireddi, P.; Yang, J.; Muller, M.; et al. MCUR1 is an essential component of mitochondrial $\mathrm{Ca}^{2+}$ uptake that regulates cellular metabolism. Nat. Cell Biol. 2012, 14, 1336-1343. [CrossRef] [PubMed] 
50. Hoffman, N.E.; Chandramoorthy, H.C.; Shanmughapriya, S.; Zhang, X.Q.; Vallem, S.; Doonan, P.J.; Malliankaraman, K.; Guo, S.; Rajan, S.; Elrod, J.W.; et al. SLC25A23 augments mitochondrial Ca ${ }^{2+}$ uptake, interacts with MCU, and induces oxidative stress-mediated cell death. Mol. Biol. Cell 2014, 25, 936-947. [CrossRef] [PubMed]

51. Trenker, M.; Malli, R.; Fertschai, I.; Levak-Frank, S.; Graier, W.F. Uncoupling proteins 2 and 3 are fundamental for mitochondrial $\mathrm{Ca}^{2+}$ uniport. Nat. Cell Biol. 2007, 9, 445-452. [CrossRef] [PubMed]

52. Dong, Z.; Shanmughapriya, S.; Tomar, D.; Siddiqui, N.; Lynch, S.; Nemani, N.; Breves, S.L.; Zhang, X.; Tripathi, A.; Palaniappan, P.; et al. Mitochondrial $\mathrm{Ca}^{2+}$ uniporter is a mitochondrial luminal redox sensor that augments mcu channel activity. Mol. Cell 2017, 65, 1014-1028. [CrossRef] [PubMed]

53. Denton, R.M.; Hughes, W.A. Pyruvate dehydrogenase and the hormonal regulation of fat synthesis in mammalian tissues. Int. J. Biochem. 1978, 9, 545-552. [CrossRef]

54. Lawlis, V.B.; Roche, T.E. Regulation of bovine kidney alpha-ketoglutarate dehydrogenase complex by calcium ion and adenine nucleotides. Effects on s0.5 for alpha-ketoglutarate. Biochemistry 1981, 20, 2512-2518. [CrossRef] [PubMed]

55. Mitchell, P. Coupling of phosphorylation to electron and hydrogen transfer by a chemi-osmotic type of mechanism. Nature 1961, 191, 144-148. [CrossRef] [PubMed]

56. Forkink, M.; Basit, F.; Teixeira, J.; Swarts, H.G.; Koopman, W.J.; Willems, P.H. Complex I and complex III inhibition specifically increase cytosolic hydrogen peroxide levels without inducing oxidative stress in HEK293 cells. Redox Biol. 2015, 6, 607-616. [CrossRef] [PubMed]

57. Murphy, M.P. How mitochondria produce reactive oxygen species. Biochem. J. 2009, 417, 1-13. [CrossRef] [PubMed]

58. Sies, H. Hydrogen peroxide as a central redox signaling molecule in physiological oxidative stress: Oxidative eustress. Redox Biol. 2017, 11, 613-619. [CrossRef] [PubMed]

59. Chen, L.; Na, R.; Gu, M.; Salmon, A.B.; Liu, Y.; Liang, H.; Qi, W.; Van Remmen, H.; Richardson, A.; Ran, Q. Reduction of mitochondrial $\mathrm{H}_{2} \mathrm{O}_{2}$ by overexpressing peroxiredoxin 3 improves glucose tolerance in mice. Aging Cell 2008, 7, 866-878. [CrossRef] [PubMed]

60. Zwerschke, W.; Mazurek, S.; Stockl, P.; Hutter, E.; Eigenbrodt, E.; Jansen-Durr, P. Metabolic analysis of senescent human fibroblasts reveals a role for AMP in cellular senescence. Biochem. J. 2003, 376, 403-411. [CrossRef] [PubMed]

61. Merry, T.L.; Ristow, M. Mitohormesis in exercise training. Free Radic. Biol. Med. 2016, 98, 123-130. [CrossRef] [PubMed]

62. Hekimi, S. Enhanced immunity in slowly aging mutant mice with high mitochondrial oxidative stress. Oncoimmunology 2013, 2, e23793. [CrossRef] [PubMed]

63. Yee, C.; Yang, W.; Hekimi, S. The intrinsic apoptosis pathway mediates the pro-longevity response to mitochondrial ros in C. elegans. Cell 2014, 157, 897-909. [CrossRef] [PubMed]

64. Duchen, M.R. Mitochondria and calcium: From cell signalling to cell death. J. Phys. 2000, 529, 57-68. [CrossRef]

65. Frezza, C.; Cipolat, S.; Martins de Brito, O.; Micaroni, M.; Beznoussenko, G.V.; Rudka, T.; Bartoli, D.; Polishuck, R.S.; Danial, N.N.; De Strooper, B.; et al. OPA1 controls apoptotic cristae remodeling independently from mitochondrial fusion. Cell 2006, 126, 177-189. [CrossRef] [PubMed]

66. Logsdon, M.D.; Meyn, R.E., Jr.; Besa, P.C.; Pugh, W.C.; Stephens, L.C.; Peters, L.J.; Milas, L.; Cox, J.D.; Cabanillas, F.; Brisbay, S.; et al. Apoptosis and the BCL-2 gene family-patterns of expression and prognostic value in STAGE I and II follicular center lymphoma. Int. J. Radiat. Oncol. Biol. Phys. 1999, 44, 19-29. [CrossRef]

67. Fesik, S.W.; Shi, Y. Structural biology. Controlling the caspases. Science 2001, 294, 1477-1478. [CrossRef] [PubMed]

68. Cerella, C.; Grandjenette, C.; Dicato, M.; Diederich, M. Roles of apoptosis and cellular senescence in cancer and aging. Curr. Drug Targets 2016, 17, 405-415. [CrossRef] [PubMed]

69. Calvo-Rodriguez, M.; Garcia-Durillo, M.; Villalobos, C.; Nunez, L. In vitro aging promotes endoplasmic reticulum ER-mitochondria $\mathrm{Ca}^{2+}$ cross talk and loss of store-operated $\mathrm{Ca}^{2+}$ entry (SOCE) in rat hippocampal neurons. Biochim. Biophys. Acta 2016, 1863, 2637-2649. [CrossRef] [PubMed] 
70. Wiel, C.; Lallet-Daher, H.; Gitenay, D.; Gras, B.; Le Calve, B.; Augert, A.; Ferrand, M.; Prevarskaya, N.; Simonnet, H.; Vindrieux, D.; et al. Endoplasmic reticulum calcium release through ITPR2 channels leads to mitochondrial calcium accumulation and senescence. Nat. Commun. 2014, 5, 3792. [CrossRef] [PubMed]

71. Gorlach, A.; Bertram, K.; Hudecova, S.; Krizanova, O. Calcium and ROS: A mutual interplay. Redox Biol. 2015, 6, 260-271. [CrossRef] [PubMed]

72. Rottenberg, H.; Hoek, J.B. The path from mitochondrial ros to aging runs through the mitochondrial permeability transition pore. Aging Cell 2017, 16, 943-955. [CrossRef] [PubMed]

73. Alvarez-Illera, P.; Garcia-Casas, P.; Arias-Del-Val, J.; Fonteriz, R.I.; Alvarez, J.; Montero, M. Pharynx mitochondrial $\left[\mathrm{Ca}^{2+}\right]$ dynamics in live C. elegans worms during aging. Oncotarget 2017, 8, 55889-55900. [CrossRef] [PubMed]

74. Uzhachenko, R.; Boyd, K.; Olivares-Villagomez, D.; Zhu, Y.; Goodwin, J.S.; Rana, T.; Shanker, A.; Tan, W.J.; Bondar, T.; Medzhitov, R.; et al. Mitochondrial protein Fus1/Tusc2 in premature aging and age-related pathologies: Critical roles of calcium and energy homeostasis. Aging 2017, 9, 627-649. [CrossRef] [PubMed]

75. Bruss, M.D.; Khambatta, C.F.; Ruby, M.A.; Aggarwal, I.; Hellerstein, M.K. Calorie restriction increases fatty acid synthesis and whole body fat oxidation rates. Am. J. Physiol. Endocrinol. Metab. 2010, 298, E108-E116. [CrossRef] [PubMed]

76. Pugh, T.D.; Conklin, M.W.; Evans, T.D.; Polewski, M.A.; Barbian, H.J.; Pass, R.; Anderson, B.D.; Colman, R.J.; Eliceiri, K.W.; Keely, P.J.; et al. A shift in energy metabolism anticipates the onset of sarcopenia in rhesus monkeys. Aging Cell 2013, 12, 672-681. [CrossRef] [PubMed]

77. Schriner, S.E.; Linford, N.J.; Martin, G.M.; Treuting, P.; Ogburn, C.E.; Emond, M.; Coskun, P.E.; Ladiges, W.; Wolf, N.; Van Remmen, H.; et al. Extension of murine life span by overexpression of catalase targeted to mitochondria. Science 2005, 308, 1909-1911. [CrossRef] [PubMed]

78. Perez, V.I.; Van Remmen, H.; Bokov, A.; Epstein, C.J.; Vijg, J.; Richardson, A. The overexpression of major antioxidant enzymes does not extend the lifespan of mice. Aging Cell 2009, 8, 73-75. [CrossRef] [PubMed]

79. Perez, V.I.; Cortez, L.A.; Lew, C.M.; Rodriguez, M.; Webb, C.R.; Van Remmen, H.; Chaudhuri, A.; Qi, W.; Lee, S.; Bokov, A.; et al. Thioredoxin 1 overexpression extends mainly the earlier part of life span in mice. J. Gerontol. A Biol. Sci. Med. Sci. 2011, 66, 1286-1299. [CrossRef] [PubMed]

80. Navarro, A.; Boveris, A. Rat brain and liver mitochondria develop oxidative stress and lose enzymatic activities on aging. Am. J. Physiol. Regul. Integr. Comp. Physiol. 2004, 287, R1244-R1249. [CrossRef] [PubMed]

81. Gauba, E.; Guo, L.; Du, H. Cyclophilin D promotes brain mitochondrial $\mathrm{F}_{1} \mathrm{~F}_{\mathrm{O}}$ ATP synthase dysfunction in aging mice. J. Alzheimers Dis. 2017, 55, 1351-1362. [CrossRef] [PubMed]

82. Tepp, K.; Puurand, M.; Timohhina, N.; Adamson, J.; Klepinin, A.; Truu, L.; Shevchuk, I.; Chekulayev, V.; Kaambre, T. Changes in the mitochondrial function and in the efficiency of energy transfer pathways during cardiomyocyte aging. Mol. Cell. Biochem. 2017, 432, 141-158. [CrossRef] [PubMed]

83. Tuppen, H.A.; Blakely, E.L.; Turnbull, D.M.; Taylor, R.W. Mitochondrial DNA mutations and human disease. Biochim. Biophys. Acta 2010, 1797, 113-128. [CrossRef] [PubMed]

84. DeBalsi, K.L.; Hoff, K.E.; Copeland, W.C. Role of the mitochondrial DNA replication machinery in mitochondrial DNA mutagenesis, aging and age-related diseases. Ageing Res. Rev. 2017, 33, 89-104. [CrossRef] [PubMed]

85. Pinto, M.; Pickrell, A.M.; Wang, X.; Bacman, S.R.; Yu, A.; Hida, A.; Dillon, L.M.; Morton, P.D.; Malek, T.R.; Williams, S.L.; et al. Transient mitochondrial DNA double strand breaks in mice cause accelerated aging phenotypes in a ROS-dependent but p53/p21-independent manner. Cell Death Differ. 2017, 24, 288-299. [CrossRef] [PubMed]

86. Latorre-Pellicer, A.; Moreno-Loshuertos, R.; Lechuga-Vieco, A.V.; Sanchez-Cabo, F.; Torroja, C.; Acin-Perez, R.; Calvo, E.; Aix, E.; Gonzalez-Guerra, A.; Logan, A.; et al. Mitochondrial and nuclear DNA matching shapes metabolism and healthy ageing. Nature 2016, 535, 561-565. [CrossRef] [PubMed]

87. Li, H.; Shen, L.; Hu, P.; Huang, R.; Cao, Y.; Deng, J.; Yuan, W.; Liu, D.; Yang, J.; Gu, H.; et al. Aging-associated mitochondrial DNA mutations alter oxidative phosphorylation machinery and cause mitochondrial dysfunctions. Biochim. Biophys. Acta 2017, 1863, 2266-2273. [CrossRef] [PubMed]

88. Lin, Y.F.; Schulz, A.M.; Pellegrino, M.W.; Lu, Y.; Shaham, S.; Haynes, C.M. Maintenance and propagation of a deleterious mitochondrial genome by the mitochondrial unfolded protein response. Nature 2016, 533, 416-419. [CrossRef] [PubMed] 
89. Babayev, E.; Wang, T.; Szigeti-Buck, K.; Lowther, K.; Taylor, H.S.; Horvath, T.; Seli, E. Reproductive aging is associated with changes in oocyte mitochondrial dynamics, function, and mtDNA quantity. Maturitas 2016, 93, 121-130. [CrossRef] [PubMed]

90. Corral-Debrinski, M.; Horton, T.; Lott, M.T.; Shoffner, J.M.; Beal, M.F.; Wallace, D.C. Mitochondrial DNA deletions in human brain: Regional variability and increase with advanced age. Nat. Genet. 1992, 2, 324-329. [CrossRef] [PubMed]

91. Bender, A.; Krishnan, K.J.; Morris, C.M.; Taylor, G.A.; Reeve, A.K.; Perry, R.H.; Jaros, E.; Hersheson, J.S.; Betts, J.; Klopstock, T.; et al. High levels of mitochondrial DNA deletions in substantia nigra neurons in aging and parkinson disease. Nat. Genet. 2006, 38, 515-517. [CrossRef] [PubMed]

92. Kraytsberg, Y.; Kudryavtseva, E.; McKee, A.C.; Geula, C.; Kowall, N.W.; Khrapko, K. Mitochondrial DNA deletions are abundant and cause functional impairment in aged human substantia nigra neurons. Nat. Genet. 2006, 38, 518-520. [CrossRef] [PubMed]

93. Bua, E.; Johnson, J.; Herbst, A.; Delong, B.; McKenzie, D.; Salamat, S.; Aiken, J.M. Mitochondrial DNA-deletion mutations accumulate intracellularly to detrimental levels in aged human skeletal muscle fibers. Am. J. Hum. Genet. 2006, 79, 469-480. [CrossRef] [PubMed]

94. Fiorese, C.J.; Schulz, A.M.; Lin, Y.F.; Rosin, N.; Pellegrino, M.W.; Haynes, C.M. The transcription factor ATF5 mediates a mammalian mitochondrial UPR. Curr. Biol. 2016, 26, 2037-2043. [CrossRef] [PubMed]

95. Nargund, A.M.; Fiorese, C.J.; Pellegrino, M.W.; Deng, P.; Haynes, C.M. Mitochondrial and nuclear accumulation of the transcription factor ATFS-1 promotes OXPHOS recovery during the UPR ${ }^{\mathrm{mt}}$. Mol. Cell 2015, 58, 123-133. [CrossRef] [PubMed]

96. Merkwirth, C.; Jovaisaite, V.; Durieux, J.; Matilainen, O.; Jordan, S.D.; Quiros, P.M.; Steffen, K.K.; Williams, E.G.; Mouchiroud, L.; Tronnes, S.U.; et al. Two conserved histone demethylases regulate mitochondrial stress-induced longevity. Cell 2016, 165, 1209-1223. [CrossRef] [PubMed]

97. Borch Jensen, M.; Qi, Y.; Riley, R.; Rabkina, L.; Jasper, H. PGAM5 promotes lasting FoxO activation after developmental mitochondrial stress and extends lifespan in Drosophila. eLife 2017, 6, e26952. [CrossRef] [PubMed]

98. Tian, Y.; Merkwirth, C.; Dillin, A. Mitochondrial UPR: A double-edged sword. Trends Cell Biol. 2016, 26, 563-565. [CrossRef] [PubMed]

99. Palikaras, K.; Lionaki, E.; Tavernarakis, N. Coordination of mitophagy and mitochondrial biogenesis during ageing in C. elegans. Nature 2015, 521, 525-528. [CrossRef] [PubMed]

100. Shirihai, O.S.; Song, M.; Dorn, G.W., II. How mitochondrial dynamism orchestrates mitophagy. Circ. Res. 2015, 116, 1835-1849. [CrossRef] [PubMed]

101. Mao, K.; Wang, K.; Liu, X.; Klionsky, D.J. The scaffold protein Atg11 recruits fission machinery to drive selective mitochondria degradation by autophagy. Dev. Cell 2013, 26, 9-18. [CrossRef] [PubMed]

102. Morozov, Y.M.; Datta, D.; Paspalas, C.D.; Arnsten, A.F.T. Ultrastructural evidence for impaired mitochondrial fission in the aged rhesus monkey dorsolateral prefrontal cortex. Neurobiol. Aging 2017, 51, 9-18. [CrossRef] [PubMed]

103. Rana, A.; Oliveira, M.P.; Khamoui, A.V.; Aparicio, R.; Rera, M.; Rossiter, H.B.; Walker, D.W. Promoting Drp1-mediated mitochondrial fission in midlife prolongs healthy lifespan of Drosophila melanogaster. Nat. Commun. 2017, 8, 448. [CrossRef] [PubMed]

104. Halling, J.F.; Ringholm, S.; Olesen, J.; Prats, C.; Pilegaard, H. Exercise training protects against aging-induced mitochondrial fragmentation in mouse skeletal muscle in a PGC-1 $\alpha$ dependent manner. Exp. Gerontol. 2017, 96, 1-6. [CrossRef] [PubMed]

105. Shen, Q.; Yamano, K.; Head, B.P.; Kawajiri, S.; Cheung, J.T.; Wang, C.; Cho, J.H.; Hattori, N.; Youle, R.J.; van der Bliek, A.M. Mutations in FIS1 disrupt orderly disposal of defective mitochondria. Mol. Biol. Cell 2014, 25, 145-159. [CrossRef] [PubMed]

106. Yamano, K.; Fogel, A.I.; Wang, C.; van der Bliek, A.M.; Youle, R.J. Mitochondrial Rab GAPs govern autophagosome biogenesis during mitophagy. eLife 2014, 3, e01612. [CrossRef] [PubMed]

107. Tezze, C.; Romanello, V.; Desbats, M.A.; Fadini, G.P.; Albiero, M.; Favaro, G.; Ciciliot, S.; Soriano, M.E.; Morbidoni, V.; Cerqua, C.; et al. Age-associated loss of OPA1 in muscle impacts muscle mass, metabolic homeostasis, systemic inflammation, and epithelial senescence. Cell Metab. 2017, 25, 1374-1389. [CrossRef] [PubMed] 
108. Jiang, Y.F.; Lin, S.S.; Chen, J.M.; Tsai, H.Z.; Hsieh, T.S.; Fu, C.Y. Electron tomographic analysis reveals ultrastructural features of mitochondrial cristae architecture which reflect energetic state and aging. Sci. Rep. 2017, 7, 45474. [CrossRef] [PubMed]

109. Brandt, T.; Mourier, A.; Tain, L.S.; Partridge, L.; Larsson, N.G.; Kuhlbrandt, W. Changes of mitochondrial ultrastructure and function during ageing in mice and Drosophila. eLife 2017, 6, e24662. [CrossRef] [PubMed]

110. El'darov Ch, M.; Vays, V.B.; Vangeli, I.M.; Kolosova, N.G.; Bakeeva, L.E. Morphometric examination of mitochondrial ultrastructure in aging cardiomyocytes. Biochemistry 2015, 80, 604-609. [CrossRef] [PubMed]

111. Yi, J.K.; Xu, R.; Jeong, E.; Mileva, I.; Truman, J.P.; Lin, C.L.; Wang, K.; Snider, J.; Wen, S.; Obeid, L.M.; et al. Aging-related elevation of sphingoid bases shortens yeast chronological life span by compromising mitochondrial function. Oncotarget 2016, 7, 21124-21144. [CrossRef] [PubMed]

112. Lee, G.D.; Wilson, M.A.; Zhu, M.; Wolkow, C.A.; de Cabo, R.; Ingram, D.K.; Zou, S. Dietary deprivation extends lifespan in Caenorhabditis elegans. Aging Cell 2006, 5, 515-524. [CrossRef] [PubMed]

113. Mattison, J.A.; Colman, R.J.; Beasley, T.M.; Allison, D.B.; Kemnitz, J.W.; Roth, G.S.; Ingram, D.K.; Weindruch, R.; de Cabo, R.; Anderson, R.M. Caloric restriction improves health and survival of rhesus monkeys. Nat. Commun. 2017, 8, 14063. [CrossRef] [PubMed]

114. Picca, A.; Pesce, V.; Lezza, A.M.S. Does eating less make you live longer and better? An update on calorie restriction. Clin. Interv. Aging 2017, 12, 1887-1902. [CrossRef] [PubMed]

115. Lopez-Lluch, G.; Navas, P. Calorie restriction as an intervention in ageing. J. Physiol. 2016, 594, $2043-2060$. [CrossRef] [PubMed]

116. Trepanowski, J.F.; Canale, R.E.; Marshall, K.E.; Kabir, M.M.; Bloomer, R.J. Impact of caloric and dietary restriction regimens on markers of health and longevity in humans and animals: A summary of available findings. Nutr. J. 2011, 10, 107. [CrossRef] [PubMed]

117. Amigo, I.; Menezes-Filho, S.L.; Luevano-Martinez, L.A.; Chausse, B.; Kowaltowski, A.J. Caloric restriction increases brain mitochondrial calcium retention capacity and protects against excitotoxicity. Aging Cell 2017, 16, 73-81. [CrossRef] [PubMed]

118. Ristow, M. Unraveling the truth about antioxidants: Mitohormesis explains ROS-induced health benefits. Nat. Med. 2014, 20, 709-711. [CrossRef] [PubMed]

119. Menezes-Filho, S.L.; Amigo, I.; Prado, F.M.; Ferreira, N.C.; Koike, M.K.; Pinto, I.F.D.; Miyamoto, S.; Montero, E.F.S.; Medeiros, M.H.G.; Kowaltowski, A.J. Caloric restriction protects livers from ischemia/reperfusion damage by preventing $\mathrm{Ca}^{2+}$-induced mitochondrial permeability transition. Free Radic. Biol. Med. 2017, 110, 219-227. [CrossRef] [PubMed]

120. Wierman, M.B.; Maqani, N.; Strickler, E.; Li, M.; Smith, J.S. Caloric restriction extends yeast chronological life span by optimizing the Snf1 (AMPK) signaling pathway. Mol. Cell. Biol. 2017, 37, e00562-16. [CrossRef] [PubMed]

121. Dong, D.; Cai, G.Y.; Ning, Y.C.; Wang, J.C.; Lv, Y.; Hong, Q.; Cui, S.Y.; Fu, B.; Guo, Y.N.; Chen, X.M. Alleviation of senescence and epithelial-mesenchymal transition in aging kidney by short-term caloric restriction and caloric restriction mimetics via modulation of AMPK/mTOR signaling. Oncotarget 2017, 8, 16109-16121. [CrossRef] [PubMed]

122. Canto, C.; Gerhart-Hines, Z.; Feige, J.N.; Lagouge, M.; Noriega, L.; Milne, J.C.; Elliott, P.J.; Puigserver, P.; Auwerx, J. AMPK regulates energy expenditure by modulating $\mathrm{NAD}^{+}$metabolism and SIRT1 activity. Nature 2009, 458, 1056-1060. [CrossRef] [PubMed]

123. Marin, T.L.; Gongol, B.; Zhang, F.; Martin, M.; Johnson, D.A.; Xiao, H.; Wang, Y.; Subramaniam, S.; Chien, S.; Shyy, J.Y. AMPK promotes mitochondrial biogenesis and function by phosphorylating the epigenetic factors DNMT1, RBBP7, and HAT1. Sci. Signal. 2017, 10, eaaf7478. [CrossRef] [PubMed]

124. Civitarese, A.E.; Carling, S.; Heilbronn, L.K.; Hulver, M.H.; Ukropcova, B.; Deutsch, W.A.; Smith, S.R.; Ravussin, E.; Team, C.P. Calorie restriction increases muscle mitochondrial biogenesis in healthy humans. PLoS Med. 2007, 4, e76. [CrossRef] [PubMed]

125. Sparks, L.M.; Redman, L.M.; Conley, K.E.; Harper, M.E.; Yi, F.; Hodges, A.; Eroshkin, A.; Costford, S.R.; Gabriel, M.E.; Shook, C.; et al. Effects of 12 months of caloric restriction on muscle mitochondrial function in healthy individuals. J. Clin. Endocrinol. Metab. 2017, 102, 111-121. [CrossRef] [PubMed]

126. Joseph, A.M.; Adhihetty, P.J.; Leeuwenburgh, C. Beneficial effects of exercise on age-related mitochondrial dysfunction and oxidative stress in skeletal muscle. J. Physiol. 2016, 594, 5105-5123. [CrossRef] [PubMed] 
127. Kang, C.; Chung, E.; Diffee, G.; Ji, L.L. Exercise training attenuates aging-associated mitochondrial dysfunction in rat skeletal muscle: Role of PGC-1 $\alpha$. Exp. Gerontol. 2013, 48, 1343-1350. [CrossRef] [PubMed]

128. Gioscia-Ryan, R.A.; Battson, M.L.; Cuevas, L.M.; Zigler, M.C.; Sindler, A.L.; Seals, D.R. Voluntary aerobic exercise increases arterial resilience and mitochondrial health with aging in mice. Aging 2016, 8, 2897-2914. [CrossRef] [PubMed]

129. Safdar, A.; Khrapko, K.; Flynn, J.M.; Saleem, A.; De Lisio, M.; Johnston, A.P.; Kratysberg, Y.; Samjoo, I.A.; Kitaoka, Y.; Ogborn, D.I.; et al. Exercise-induced mitochondrial p53 repairs mtdna mutations in mutator mice. Skelet. Muscle 2016, 6, 7. [CrossRef] [PubMed]

130. Howitz, K.T.; Bitterman, K.J.; Cohen, H.Y.; Lamming, D.W.; Lavu, S.; Wood, J.G.; Zipkin, R.E.; Chung, P.; Kisielewski, A.; Zhang, L.L.; et al. Small molecule activators of sirtuins extend saccharomyces cerevisiae lifespan. Nature 2003, 425, 191-196. [CrossRef] [PubMed]

131. Wilson, M.A.; Shukitt-Hale, B.; Kalt, W.; Ingram, D.K.; Joseph, J.A.; Wolkow, C.A. Blueberry polyphenols increase lifespan and thermotolerance in Caenorhabditis elegans. Aging Cell 2006, 5, 59-68. [CrossRef] [PubMed]

132. Lopez, T.; Schriner, S.E.; Okoro, M.; Lu, D.; Chiang, B.T.; Huey, J.; Jafari, M. Green tea polyphenols extend the lifespan of male Drosophila melanogaster while impairing reproductive fitness. J. Med. Food 2014, 17, 1314-1321. [CrossRef] [PubMed]

133. Valenzano, D.R.; Terzibasi, E.; Genade, T.; Cattaneo, A.; Domenici, L.; Cellerino, A. Resveratrol prolongs lifespan and retards the onset of age-related markers in a short-lived vertebrate. Curr. Biol. 2006, 16, $296-300$. [CrossRef] [PubMed]

134. Baur, J.A.; Pearson, K.J.; Price, N.L.; Jamieson, H.A.; Lerin, C.; Kalra, A.; Prabhu, V.V.; Allard, J.S.; Lopez-Lluch, G.; Lewis, K.; et al. Resveratrol improves health and survival of mice on a high-calorie diet. Nature 2006, 444, 337-342. [CrossRef] [PubMed]

135. Ferrieres, J. The French paradox: Lessons for other countries. Heart 2004, 90, 107-111. [CrossRef] [PubMed]

136. Berman, A.Y.; Motechin, R.A.; Wiesenfeld, M.Y.; Holz, M.K. The therapeutic potential of resveratrol: A review of clinical trials. NPJ Precis. Oncol. 2017, 1, 35. [CrossRef] [PubMed]

137. Manzo-Avalos, S.; Saavedra-Molina, A. Cellular and mitochondrial effects of alcohol consumption. Int. J. Environ. Res. Public Health 2010, 7, 4281-4304. [CrossRef] [PubMed]

138. Dehghan, M.; Mente, A.; Zhang, X.; Swaminathan, S.; Li, W.; Mohan, V.; Iqbal, R.; Kumar, R.; Wentzel-Viljoen, E.; Rosengren, A.; et al. Associations of fats and carbohydrate intake with cardiovascular disease and mortality in 18 countries from five continents (PURE): A prospective cohort study. Lancet 2017, 390, 2050-2062. [CrossRef]

139. Chung, J.H.; Manganiello, V.; Dyck, J.R. Resveratrol as a calorie restriction mimetic: Therapeutic implications. Trends Cell Biol. 2012, 22, 546-554. [CrossRef] [PubMed]

140. Borra, M.T.; Smith, B.C.; Denu, J.M. Mechanism of human SIRT1 activation by resveratrol. J. Biol. Chem. 2005, 280, 17187-17195. [CrossRef] [PubMed]

141. Kaeberlein, M.; McDonagh, T.; Heltweg, B.; Hixon, J.; Westman, E.A.; Caldwell, S.D.; Napper, A.; Curtis, R.; DiStefano, P.S.; Fields, S.; et al. Substrate-specific activation of sirtuins by resveratrol. J. Biol. Chem. 2005, 280, 17038-17045. [CrossRef] [PubMed]

142. Brenmoehl, J.; Hoeflich, A. Dual control of mitochondrial biogenesis by sirtuin 1 and sirtuin 3. Mitochondrion 2013, 13, 755-761. [CrossRef] [PubMed]

143. Madreiter-Sokolowski, C.T.; Sokolowski, A.A.; Graier, W.F. Dosis facit sanitatem-concentration-dependent effects of resveratrol on mitochondria. Nutrients 2017, 9, e1117. [CrossRef] [PubMed]

144. Mungai, P.T.; Waypa, G.B.; Jairaman, A.; Prakriya, M.; Dokic, D.; Ball, M.K.; Schumacker, P.T. Hypoxia triggers AMPK activation through reactive oxygen species-mediated activation of calcium release-activated calcium channels. Mol. Cell. Biol. 2011, 31, 3531-3545. [CrossRef] [PubMed]

145. Ristow, M.; Schmeisser, K. Mitohormesis: Promoting health and lifespan by increased levels of reactive oxygen species (ROS). Dose Response 2014, 12, 288-341. [CrossRef] [PubMed]

146. Chacko, B.K.; Srivastava, A.; Johnson, M.S.; Benavides, G.A.; Chang, M.J.; Ye, Y.; Jhala, N.; Murphy, M.P.; Kalyanaraman, B.; Darley-Usmar, V.M. Mitochondria-targeted ubiquinone (MitoQ) decreases ethanol-dependent micro and macro hepatosteatosis. Hepatology 2011, 54, 153-163. [CrossRef] [PubMed] 
147. Manczak, M.; Mao, P.; Calkins, M.J.; Cornea, A.; Reddy, A.P.; Murphy, M.P.; Szeto, H.H.; Park, B.; Reddy, P.H. Mitochondria-targeted antioxidants protect against amyloid- $\beta$ toxicity in Alzheimer's disease neurons. J. Alzheimers Dis. 2010, 20 (Suppl. 2), S609-S631. [CrossRef] [PubMed]

148. Ross, M.F.; Kelso, G.F.; Blaikie, F.H.; James, A.M.; Cocheme, H.M.; Filipovska, A.; Da Ros, T.; Hurd, T.R.; Smith, R.A.; Murphy, M.P. Lipophilic triphenylphosphonium cations as tools in mitochondrial bioenergetics and free radical biology. Biochemistry 2005, 70, 222-230. [CrossRef] [PubMed]

149. Trnka, J.; Blaikie, F.H.; Logan, A.; Smith, R.A.; Murphy, M.P. Antioxidant properties of MitoTEMPOL and its hydroxylamine. Free Radic. Res. 2009, 43, 4-12. [CrossRef] [PubMed]

150. Maiti, A.K.; Saha, N.C.; More, S.S.; Panigrahi, A.K.; Paul, G. Neuroprotective efficacy of mitochondrial antioxidant mitoQ in suppressing peroxynitrite-mediated mitochondrial dysfunction inflicted by lead toxicity in the rat brain. Neurotox. Res. 2017, 31, 358-372. [CrossRef] [PubMed]

151. Ward, M.S.; Flemming, N.B.; Gallo, L.A.; Fotheringham, A.K.; McCarthy, D.A.; Zhuang, A.; Tang, P.H.; Borg, D.J.; Shaw, H.; Harvie, B.; et al. Targeted mitochondrial therapy using mitoQ shows equivalent renoprotection to angiotensin converting enzyme inhibition but no combined synergy in diabetes. Sci. Rep. 2017, 7, 15190. [CrossRef] [PubMed]

152. Gioscia-Ryan, R.A.; Battson, M.L.; Cuevas, L.M.; Eng, J.S.; Murphy, M.P.; Seals, D.R. Mitochondria-targeted antioxidant therapy with mitoQ ameliorates aortic stiffening in old mice. J. Appl. Physiol. 2017. [CrossRef] [PubMed]

153. Gane, E.J.; Weilert, F.; Orr, D.W.; Keogh, G.F.; Gibson, M.; Lockhart, M.M.; Frampton, C.M.; Taylor, K.M.; Smith, R.A.; Murphy, M.P. The mitochondria-targeted anti-oxidant mitoquinone decreases liver damage in a phase II study of hepatitis C patients. Liver Int. 2010, 30, 1019-1026. [CrossRef] [PubMed]

154. Wu, J.; Hao, S.; Sun, X.R.; Zhang, H.; Li, H.; Zhao, H.; Ji, M.H.; Yang, J.J.; Li, K. Elamipretide (Ss-31) ameliorates isoflurane-induced long-term impairments of mitochondrial morphogenesis and cognition in developing rats. Front. Cell. Neurosci. 2017, 11, 119. [CrossRef] [PubMed]

155. Daubert, M.A.; Yow, E.; Dunn, G.; Marchev, S.; Barnhart, H.; Douglas, P.S.; O'Connor, C.; Goldstein, S.; Udelson, J.E.; Sabbah, H.N. Novel mitochondria-targeting peptide in heart failure treatment: A randomized, placebo-controlled trial of elamipretide. Circ. Heart Fail. 2017, 10, e004389. [CrossRef] [PubMed]

156. El-Hattab, A.W.; Zarante, A.M.; Almannai, M.; Scaglia, F. Therapies for mitochondrial diseases and current clinical trials. Mol. Genet. Metab. 2017, 122, 1-9. [CrossRef] [PubMed]

157. Desjardins, D.; Cacho-Valadez, B.; Liu, J.L.; Wang, Y.; Yee, C.; Bernard, K.; Khaki, A.; Breton, L.; Hekimi, S. Antioxidants reveal an inverted U-shaped dose-response relationship between reactive oxygen species levels and the rate of aging in Caenorhabditis elegans. Aging Cell 2017, 16, 104-112. [CrossRef] [PubMed]

158. Conti, V.; Izzo, V.; Corbi, G.; Russomanno, G.; Manzo, V.; De Lise, F.; Di Donato, A.; Filippelli, A. Antioxidant supplementation in the treatment of aging-associated diseases. Front. Pharmacol. 2016, 7, 24. [CrossRef] [PubMed]

159. Sakellariou, G.K.; Pearson, T.; Lightfoot, A.P.; Nye, G.A.; Wells, N.; Giakoumaki, I.I.; Griffiths, R.D.; McArdle, A.; Jackson, M.J. Long-term administration of the mitochondria-targeted antioxidant mitoquinone mesylate fails to attenuate age-related oxidative damage or rescue the loss of muscle mass and function associated with aging of skeletal muscle. FASEB J. 2016, 30, 3771-3785. [CrossRef] [PubMed]

160. Shabalina, I.G.; Vyssokikh, M.Y.; Gibanova, N.; Csikasz, R.I.; Edgar, D.; Hallden-Waldemarson, A.; Rozhdestvenskaya, Z.; Bakeeva, L.E.; Vays, V.B.; Pustovidko, A.V.; et al. Improved health-span and lifespan in mtDNA mutator mice treated with the mitochondrially targeted antioxidant SkQ1. Aging 2017, 9, 315-339. [CrossRef] [PubMed]

161. Huang, X.B.; Mu, X.H.; Wan, Q.L.; He, X.M.; Wu, G.S.; Luo, H.R. Aspirin increases metabolism through germline signalling to extend the lifespan of Caenorhabditis elegans. PLoS ONE 2017, 12, e0184027. [CrossRef] [PubMed]

162. Danilov, A.; Shaposhnikov, M.; Shevchenko, O.; Zemskaya, N.; Zhavoronkov, A.; Moskalev, A. Influence of non-steroidal anti-inflammatory drugs on Drosophila melanogaster longevity. Oncotarget 2015, 6, 19428-19444. [CrossRef] [PubMed]

163. Strong, R.; Miller, R.A.; Astle, C.M.; Floyd, R.A.; Flurkey, K.; Hensley, K.L.; Javors, M.A.; Leeuwenburgh, C.; Nelson, J.F.; Ongini, E.; et al. Nordihydroguaiaretic acid and aspirin increase lifespan of genetically heterogeneous male mice. Aging Cell 2008, 7, 641-650. [CrossRef] [PubMed] 
164. Chan, A.T.; Giovannucci, E.L.; Meyerhardt, J.A.; Schernhammer, E.S.; Curhan, G.C.; Fuchs, C.S. Long-term use of aspirin and nonsteroidal anti-inflammatory drugs and risk of colorectal cancer. JAMA 2005, 294, 914-923. [CrossRef] [PubMed]

165. De Gaetano, G.; Collaborative Group of the Primary Prevention Project. Low-dose aspirin and vitamin E in people at cardiovascular risk: A randomised trial in general practice. Collaborative group of the primary prevention project. Lancet 2001, 357, 89-95. [PubMed]

166. Ridker, P.M.; Cook, N.R.; Lee, I.M.; Gordon, D.; Gaziano, J.M.; Manson, J.E.; Hennekens, C.H.; Buring, J.E. A randomized trial of low-dose aspirin in the primary prevention of cardiovascular disease in women. N. Engl. J. Med. 2005, 352, 1293-1304. [CrossRef] [PubMed]

167. Sorensen, H.T.; Mellemkjaer, L.; Blot, W.J.; Nielsen, G.L.; Steffensen, F.H.; McLaughlin, J.K.; Olsen, J.H. Risk of upper gastrointestinal bleeding associated with use of low-dose aspirin. Am. J. Gastroenterol. 2000, 95, 2218-2224. [CrossRef] [PubMed]

168. Qi, W.; Gutierrez, G.E.; Gao, X.; Dixon, H.; McDonough, J.A.; Marini, A.M.; Fisher, A.L. The $\omega-3$ fatty acid $\alpha$-linolenic acid extends Caenorhabditis elegans lifespan via NHR-49/PPAR $\alpha$ and oxidation to oxylipins. Aging Cell 2017, 16, 1125-1135. [CrossRef] [PubMed]

169. Afshordel, S.; Hagl, S.; Werner, D.; Rohner, N.; Kogel, D.; Bazan, N.G.; Eckert, G.P. Omega-3 polyunsaturated fatty acids improve mitochondrial dysfunction in brain aging - impact of Bcl-2 and NPD-1 like metabolites. Prostaglandins Leukot. Essent. Fat. Acids 2015, 92, 23-31. [CrossRef] [PubMed]

170. Lalia, A.Z.; Dasari, S.; Robinson, M.M.; Abid, H.; Morse, D.M.; Klaus, K.A.; Lanza, I.R. Influence of omega-3 fatty acids on skeletal muscle protein metabolism and mitochondrial bioenergetics in older adults. Aging 2017, 9, 1096-1129. [CrossRef] [PubMed]

171. Bridges, H.R.; Jones, A.J.; Pollak, M.N.; Hirst, J. Effects of metformin and other biguanides on oxidative phosphorylation in mitochondria. Biochem. J. 2014, 462, 475-487. [CrossRef] [PubMed]

172. Cuyas, E.; Fernandez-Arroyo, S.; Joven, J.; Menendez, J.A. Metformin targets histone acetylation in cancer-prone epithelial cells. Cell Cycle 2016, 15, 3355-3361. [CrossRef] [PubMed]

173. Wu, L.; Zhou, B.; Oshiro-Rapley, N.; Li, M.; Paulo, J.A.; Webster, C.M.; Mou, F.; Kacergis, M.C.; Talkowski, M.E.; Carr, C.E.; et al. An ancient, unified mechanism for metformin growth inhibition in C. elegans and cancer. Cell 2016, 167, 1705-1718. [CrossRef] [PubMed]

174. Kalender, A.; Selvaraj, A.; Kim, S.Y.; Gulati, P.; Brule, S.; Viollet, B.; Kemp, B.E.; Bardeesy, N.; Dennis, P.; Schlager, J.J.; et al. Metformin, independent of AMPK, inhibits mTORC1 in a rag GTPase-dependent manner. Cell Metab. 2010, 11, 390-401. [CrossRef] [PubMed]

175. Morita, M.; Gravel, S.P.; Hulea, L.; Larsson, O.; Pollak, M.; St-Pierre, J.; Topisirovic, I. mTOR coordinates protein synthesis, mitochondrial activity and proliferation. Cell Cycle 2015, 14, 473-480. [CrossRef] [PubMed]

176. Andrzejewski, S.; Gravel, S.P.; Pollak, M.; St-Pierre, J. Metformin directly acts on mitochondria to alter cellular bioenergetics. Cancer Metab. 2014, 2, 12. [CrossRef] [PubMed]

177. Smieszek, A.; Strek, Z.; Kornicka, K.; Grzesiak, J.; Weiss, C.; Marycz, K. Antioxidant and anti-senescence effect of metformin on mouse olfactory ensheathing cells (mOECs) may be associated with increased brain-derived neurotrophic factor levels—an ex vivo study. Int. J. Mol. Sci. 2017, 18, e872. [CrossRef] [PubMed]

178. Sylow, L.; Long, J.Z.; Lokurkar, I.A.; Zeng, X.; Richter, E.A.; Spiegelman, B.M. The cancer drug dasatinib increases PGC- $1 \alpha$ in adipose tissue but has adverse effects on glucose tolerance in obese mice. Endocrinology 2016, 157, 4184-4191. [CrossRef] [PubMed]

179. Guignabert, C.; Phan, C.; Seferian, A.; Huertas, A.; Tu, L.; Thuillet, R.; Sattler, C.; Le Hiress, M.; Tamura, Y.; Jutant, E.M.; et al. Dasatinib induces lung vascular toxicity and predisposes to pulmonary hypertension. J. Clin. Investig. 2016, 126, 3207-3218. [CrossRef] [PubMed]

180. Zhu, Y.; Tchkonia, T.; Fuhrmann-Stroissnigg, H.; Dai, H.M.; Ling, Y.Y.; Stout, M.B.; Pirtskhalava, T.; Giorgadze, N.; Johnson, K.O.; Giles, C.B.; et al. Identification of a novel senolytic agent, navitoclax, targeting the Bcl-2 family of anti-apoptotic factors. Aging Cell 2016, 15, 428-435. [CrossRef] [PubMed]

181. De Oliveira, M.R.; Nabavi, S.M.; Braidy, N.; Setzer, W.N.; Ahmed, T.; Nabavi, S.F. Quercetin and the mitochondria: A mechanistic view. Biotechnol. Adv. 2016, 34, 532-549. [CrossRef] [PubMed] 